\title{
UPDATE Use of botulinum toxin in musculoskeletal pain [version
}

\section{2; peer review: 2 approved, 1 approved with reservations]}

\author{
Jasvinder A Singh 1-3
}

\author{
${ }^{1}$ Medicine Service and Center for Surgical Medical Acute Care Research and Transitions (C-SMART), Birmingham Veterans Affairs \\ Medical Center, Birmingham AL, 35294, USA \\ 2Department of Medicine at School of Medicine, and Division of Epidemiology at School of Public Health, University of Alabama, \\ Birmingham AL, 35294, USA \\ ${ }^{3}$ Department of Orthopedic Surgery, Mayo Clinic College of Medicine, Rochester MN, 55123, USA
}

\author{
V2 First published: 15 Feb 2013, 2:52 \\ https://doi.org/10.12688/f1000research.2-52.v1 \\ Latest published: 24 Jul 2013, 2:52 \\ https://doi.org/10.12688/f1000research.2-52.v2
}

\section{Abstract}

Chronic musculoskeletal pain is a common cause of chronic pain, which is associated with a total cost of $\$ 635$ billion per year in the U.S. Emerging evidence suggests an anti-nociceptive action of botulinum toxin, independent of its muscle paralyzing action. This review provides a summary of data from both non-randomized and randomized clinical studies of botulinum toxin in back pain and various osteoarticular conditions, including osteoarthritis, tennis elbow, low back pain and hand pain. Three randomized controlled trials (RCTs) of small sizes provide evidence of short-term efficacy of a single intra-articular injection of 100 units of botulinum toxin A (BoNT/A) for the relief of pain and the improvement of both function and quality of life in patients with chronic joint pain due to arthritis. Three RCTs studied intramuscular BoNT/A for tennis elbow with one showing a significant improvement in pain relief compared with placebo, another one showing no difference from placebo, and the third finding that pain and function improvement with BoNT/A injection were similar to those obtained with surgical release. One RCT of intramuscular BoNT/A for low back pain found improvement in pain and function compared to placebo. Single RCTs using local injections of BoNT in patients with either temporomandibular joint (TMJ) pain or plantar fasciitis found superior efficacy compared to placebo. One RCT of intramuscular BoNT/B in patients with hand pain and carpal tunnel syndrome found improvement in pain in both BoNT/B and placebo groups, but no significant difference between groups. Most evidence is based on small studies, but the use of BoNT is supported by a single, and sometimes up to three, RCTs for several chronic musculoskeletal pain conditions. This indicates that botulinum toxin may be a promising potential new treatment for chronic refractory musculoskeletal pain. Well-designed large clinical trials are needed.

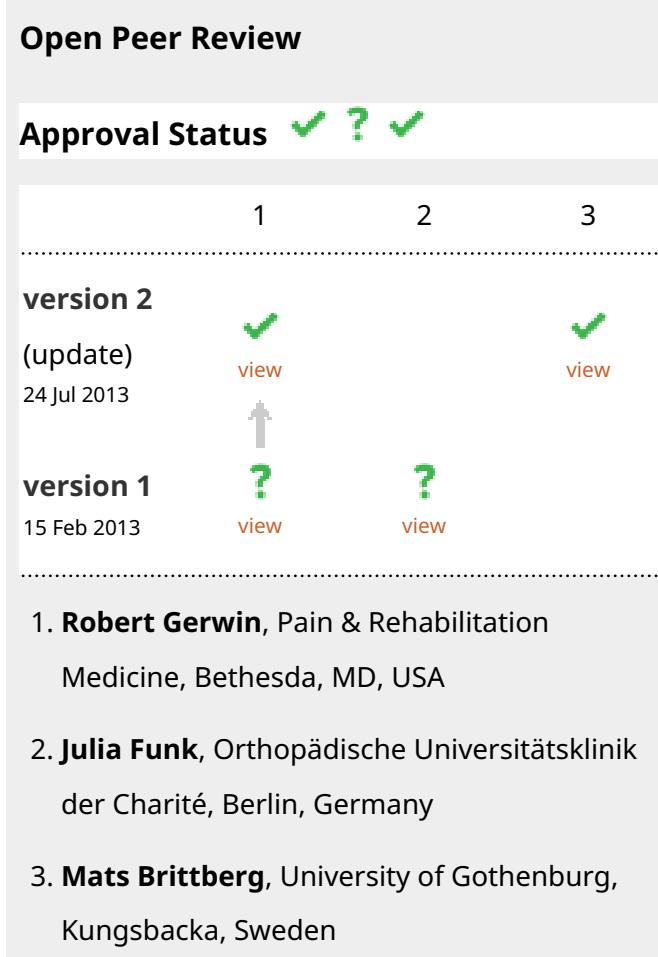

Any reports and responses or comments on the article can be found at the end of the article. 


\section{Keywords}

musculoskeletal pain, arthritis, botulinum toxin, intra-articular, pain, function

Corresponding author: Jasvinder A Singh (jasvinder.md@gmail.com)

Competing interests: There are no financial competing interests related directly to this study. JAS has received research and travel grants from Takeda, Savient, and Allergan; and consultant fees from URL pharmaceuticals, Savient, Takeda, Regeneron, Ardea, Allergan and Novartis. The views expressed in this article are those of the author and do not necessarily reflect the position or policy of the Department of Veterans Affairs or the United States government.

Grant information: No funding was obtained for this work. JAS is also supported by grants from the Agency for Health Quality and Research Center for Education and Research on Therapeutics (CERTs), National Institute of Aging and National Cancer Institute and the resources and use of facilities at the Birmingham VA Medical Center, Alabama, USA.

The funders had no role in study design, data collection and analysis, decision to publish, or preparation of the manuscript.

Copyright: $\odot 2013$ Singh JA. This is an open access article distributed under the terms of the Creative Commons Attribution License, which permits unrestricted use, distribution, and reproduction in any medium, provided the original work is properly cited.

How to cite this article: Singh JA. Use of botulinum toxin in musculoskeletal pain [version 2; peer review: 2 approved, 1 approved with reservations] F1000Research 2013, 2:52 https://doi.org/10.12688/f1000research.2-52.v2

First published: 15 Feb 2013, 2:52 https://doi.org/10.12688/f1000research.2-52.v1 


\section{UPDATED Changes from Version 1}

I have made numerous edits to the manuscript to address the comments and suggestions by the two referees. Notably, I discuss the limitations of the studies that are included in more detail, have added suggested studies, added a section on the limitations of the review and discuss the potential differences in the mechanism of action between intramuscular and intra-articular injections. I believe these changes based on the reviewers' suggestions have improved the quality of this manuscript.

See referee reports

\section{Introduction}

Pain is a major public health problem. Pain was recognized as a major challenge by the Institute of Medicine (IOM) in their recent report $^{1}$. This report highlighted that persistent pain affects 100 million Americans with a cost of $\$ 635$ billion in direct costs and lost wages. Musculoskeletal pain is the most common cause of persistent pain and is most often due to arthritis, back pain and/or local musculoskeletal conditions (such as tendinitis, bursitis, sprains), and (less commonly) injuries. In a European survey of pain prevalence in the general population, moderate to severe pain lasting 6-months or longer was reported by $19 \%$ respondents, of whom $40 \%$ ( $8 \%$ of all respondents) had joint pain ${ }^{2}$. Arthritis affects nearly 50 million adults in the U.S., and is projected to increase in prevalence to 67 million adults, or $25 \%$ of those aged 18 years and older, by the year $2030^{3}$. Arthritis is the leading cause of disability in adults $\geq 18$ years in the U.S. ${ }^{4}$, the third leading cause of work limitation in the U.S. ${ }^{5}$, is associated with 992,100 annual hospitalizations ${ }^{6}$ and 44 million annual outpatient visits 7 . In 2003, the total cost of arthritis was $\$ 128$ billion in the U.S., including $\$ 81$ billion in direct medical costs and $\$ 47$ billion in indirect costs (lost earnings) ${ }^{8}$. Back pain is a leading cause of persistent pain and is the fifth-most-common reason for physician visits ${ }^{9,10}$. Back pain was responsible for $50 \%$ of all chronic pain problems in a European survey ${ }^{2}$. In a U.S. survey, each year $15 \%$ of American adults report frequent back pain or pain lasting more than two weeks ${ }^{11}$. The annual costs of lower back pain in the U.S. exceed $\$ 100$ billion $^{12,13}$. Treatment of chronic musculoskeletal pain secondary to joint pain and/or back pain constitutes a major challenge.

All joint structures except articular cartilage are innervated with articular nerves that contain A-delta, A-beta and C-fibers ${ }^{14-17}$. In normal healthy individuals, these nociceptors have a high threshold for excitation in response to mechanical and thermal stimuli. Normal activities such as walking, stair climbing and sports (and palpation of the joint) do not cross this threshold for nociceptor activation and therefore these activities are not associated with pain or unpleasant sensations. However, joint injury or inflammation is associated with decrease in the excitation threshold of these nociceptors. This leads to enhanced responses to both innocuous and noxious mechanical, chemical and thermal stimuli. This phenomenon is called peripheral sensitization ${ }^{18}$. Chronic joint inflammation is also associated with hyperexcitability of spinal nociceptive neurons i.e., central sensitization ${ }^{19,20}$. A variety of mediators can sensitize joint nerves and nociceptors to mechanical stimuli including bradykinin, serotonin, substance $\mathrm{P}$, prostaglandin E2, prostaglandin I2 and neuropeptide $\mathrm{Y}^{17}$. Another contributor to joint pain and inflammation is neurogenic inflammation, which involves the release of neuropeptides from nerve terminals in response to inflammation, the release of neuropeptides from postganglionic sympathetic nerves due to sympathetic reflexes and the release of neuropeptides due to cytokine or neuropeptide-stimulation of local inflammatory cells $\mathrm{s}^{21}$. It is likely that these processes underlie the clinical observed signs and symptoms of pain and mechanical hyperalgesia in inflamed joints. Recent reviews describe the processes of sensitization and neurogenic inflammation and summarize our current understating of joint pain and the various mechanisms contributing to it ${ }^{17,18}$. Activation of glial cells, other immune cells and cytokines also contribute to the generation of pain ${ }^{22-27}$. The role of pain pathways, pain receptors and various contributors to both inflammatory and neuropathic pain has been summarized in recent studies and reviews ${ }^{28-33}$.

Commonly used approaches to treat musculoskeletal pain include oral therapies, intra-articular therapies, topical treatments and physical therapy. The main challenges to the use of therapies for refractory musculoskeletal pain include their limited efficacy and the risk of toxicity. Use of common oral therapies such as nonsteroidal anti-inflammatory drugs (NSAIDs), opioid medications (narcotics) and analgesics (acetaminophen etc.), which are effective for some patients with chronic musculoskeletal pain, is associated with a significant risk of side effects, especially in the elderly ${ }^{34-36}$. Common side effects include: peptic ulcer disease with its complications (bleeding and perforation), renal failure and liver toxicity in patients using NSAIDs; sedation, confusion, constipation and falls in those taking narcotics; and liver toxicity in patients taking acetaminophen. Both intra-articular therapies (including the use of corticosteroids and hyaluronic acid) as well as topical preparations such as capsaicin and lidocaine have limited efficacy in patients with osteoarthritis (OA) and/or joint pain ${ }^{37-41}$. Physical therapy is effective $^{42}$, but feasibility remains an issue as some patients are unable to adhere to physical therapy regimens due to personal preference and/or comorbidities, the need for transportation for frequent visits and the inconvenience of frequent travel and the time commitment involved. Thus, at present, limited effective and safe therapeutic options are available for refractory musculoskeletal pain. Therefore, new therapeutic options for treatment of musculoskeletal pain are needed.

Botulinum toxin (BoNT) is one of the most potent neurotoxins and consists of a $50 \mathrm{kDa}$ light chain and a $100 \mathrm{kDa}$ heavy chain linked with a disulfide bond. It exists in seven serotypes, A through G. Botulinum toxin has been shown to interfere with the expression of various neuropeptides such as substance $\mathrm{P}$ and calcitonin gene-related protein (CGRP), which are key mediators of neurogenic inflammation $^{43}$. In an animal model, botulinum toxin A (BoNT/A; Onabotulinumtoxina) injections into the rat paw reduced formalin-induced paw edema, tissue glutamate release and spinal cord electrical excitations $^{44}$. BoNT/A inhibited stimulated substance P-release ${ }^{45,46}$ and CGRP-release ${ }^{45,47,48}$ in models of acute and chronic inflammation. In vitro studies showed that BoNT/A inhibited stimulated CGRP release from rat trigeminal ganglia ${ }^{49}$ and capsaicin-stimulated substance P-release from embryonic rat dorsal root ganglia neurons ${ }^{50}$. In particular, BoNTs have been shown to inhibit cytokines, neuropeptides and other inflammatory mediators that play an important role in the pathophysiology of both rheumatoid arthritis and rat 
adjuvant arthritis (an animal model that is similar to human rheumatoid arthritis $)^{51-54}$. Thus, there is pre-clinical evidence suggesting an anti-nociceptive mechanism of action of botulinum toxin. Various clinical studies support the anti-nociceptive action of botulinum $\operatorname{toxin}^{55-57}$, while some studies have found no such evidence ${ }^{58-60}$.

The objective of this systematic review was to synthesize data from both randomized and non-randomized trials to assess the safety and efficacy of botulinum toxin in osteoarticular pain.

\section{Search strategy for literature synthesis}

In this evidence-based literature review, I performed a focused systematic review of published non-randomized (prospective and retrospective cohort studies and case series) and randomized studies of botulinum toxin for arthritis and musculoskeletal pain by performing two PubMed searches: one using the terms "botulinum toxin" and "musculoskeletal pain" and another using the terms "botulinum toxin" and "arthritis". In addition to summarizing the key studies identified from this search, I also reviewed the bibliography of key reviews to identify any studies that may have been missed using the search strategy, including our recent review of the use of botulinum toxin in osteoarticular pain ${ }^{61}$. Inclusion criteria included the use of botulinum toxin, randomized or non-randomized study that included adults with musculoskeletal pain and reported clinical outcomes. Studies of myofascial pain syndromes were not included in this review, since they have been the focus of previous reviews ${ }^{62,63}$. I summarized case reports only when they provided new evidence for a particular use of botulinum toxin. In the sections below, I summarize data that provides initial evidence for the anti-nociceptive action of botulinum toxin, followed by existing evidence related to the use of botulinum toxin in various musculoskeletal pain conditions including refractory arthritis.

Recent reviews have summarized the injectable treatments for osteoarthritis $^{64}$, injectable treatments for knee osteoarthritis ${ }^{65}$ or use of neurotoxin for the treatment of painful disorders ${ }^{66}$, In this review, I provide a review of evidence regarding botulinum toxin for the treatment of musculoskeletal pain conditions.

\section{Results}

\section{Refractory osteoarticular joint pain}

In this section, I summarize the data from non-randomized studies followed by data from randomized controlled trials (RCTs) for the efficacy of botulinum toxin's efficacy in refractory shoulder joint pain (1 randomized study) and refractory knee joint pain (2 randomized studies) (Table 1).

Non-randomized studies in patients with refractory joint pain There are three non-randomized that provide evidence for the efficacy of BoNT in cases of refractory joint pain ${ }^{67-69}$. In a retrospective study, Mahowald et al. reported the results of intra-articular injections of botulinum toxin type A (IA-BoNT/A) in 15 shoulder and lower extremity joints in 11 patients experiencing refractory pain ${ }^{67}$. All patients were receiving analgesics/NSAIDs and none had experienced relief with intra-articular corticosteroids. Patients received 25-100 units of IA-BoNT/A. There were 9 men and 2 women with an age range of 42-82 years. Joint pain was measured on a $0-10$ numeric rating scale (NRS). Pain relief began within 2 weeks in most patients. A single intra-articular injection of botulinum toxin was associated with a clinically and statistically significant decrease in pain severity and improvement in function compared to baseline: lower extremity and shoulder pain decreased from 7 to 2.7 and 8.2 to 2.4, respectively; shoulder flexion improved from 68 to 113 degrees and shoulder abduction improved from 50 to 74 degrees, respectively. Timed stand tests (the time taken to stand up ten times from a sitting position) improved from 36 to 23 seconds. The duration of relief/improvement lasted 3-10 months. None of the patients reported any adverse events and no motor-sensory deficits were found on lower extremity examination after the IABoNT/A injection.

Another report described the long-term follow-up of these 11 patients with 15 treated joints, of which ten joints were re-injected with 30-150 units of BoNT/A intra-articularly (Botox, Allergan) at the patient's request, when pain returned ${ }^{68}$. Nine of the ten re-injections were associated with pain reduction, as seen with the first injection. Pain severity decreased from 6.6 (SD, 1.2) to 3.3 (SD, 2.7) on a $0-10 \mathrm{NRS}$, which was statistically significant ( $p=0.003$ ). Pain relief lasted 3-17 months. None of the patients reported any local or systemic adverse events related to BoNT/A. One patient experienced increased joint swelling with no increase in joint pain 3 weeks after BoNT/A injection. Another patient experienced a continued increase in joint pain after BoNT/A injection, which was relieved with a subsequent BoNT/A injection.

In another case series, 11 adults with refractory pain underwent injection of botulinum toxin type A (25-100 units; Botox, Allergan) or type B (5,000 units; Myobloc, Solstice Neurosciences) into the sacroiliac, cervical/lumbar facet or sternoclavicular joints, C-2 roots and lumbar disc ${ }^{69}$. This case series comprised 9 women and 2 men with a mean age of 48 years (SD, 10 years; range, 32-68 years). Median pain scores decreased significantly after BoNT injections, with a median decrease of 3 on a $0-10$ NRS pain scale (range for pain NRS reduction, $0-5 ; \mathrm{p}=0.008$ ). Three patients experienced no change in pain severity after botulinum toxin injections, while eight experienced a decrease. No patients reported any increase in pain severity after BoNT injection. Pain reduction began within 3-5 days. Five patients received repeat injections. There was no evidence of decreasing efficacy of pain relief with repeated BoNT injections; in fact, the duration of pain relief increased with each successive treatment for 4 of the 5 patients with multiple treatments. All patients that experienced pain reduction with BoNT injections also noted improved function in activities of daily life and the range of motion in their joints. The median duration of pain relief with BoNT injections was 1.6 months longer than that seen with previous corticosteroid injections. There were no adverse events reported by the patients.

Refractory shoulder joint pain: 1 RCT comparing IA-BoNT/A injections with IA-placebo

Singh et al. performed a double-blind RCT of BoNT/A (Allergan, Inc.) into glenohumeral (shoulder) joints of patients with refractory, chronic shoulder joint pain due to osteoarthritis or rheumatoid arthritis of the shoulder joint, who had all failed conservative management $^{70}$ (Table 1). Patients were randomized to one of the two treatment groups - a single injection of 100 units of botulinum toxin 
Table 1. Efficacy of botulinum toxin in osteoarticular pain in randomized controlled trials.

\begin{tabular}{|c|c|c|c|c|c|c|}
\hline Study & $\begin{array}{l}\text { \# Patients } \\
\text { (male/female), } \\
\text { pain duration }\end{array}$ & $\begin{array}{l}\text { Study type } \\
\text { (duration) }\end{array}$ & Groups & $\begin{array}{l}\text { Mean age in } \\
\text { years (SD) }\end{array}$ & $\begin{array}{l}\text { Primary } \\
\text { outcomes }\end{array}$ & Main result - efficacy \\
\hline $\begin{array}{l}\text { Singh } \\
\text { et al. }{ }^{70}\end{array}$ & $\begin{array}{l}\mathrm{N}=36(43 \\
\text { painful } \\
\text { shoulders) } \\
(35 \mathrm{M} / 1 \mathrm{~F}) \\
8-11 \text { years }\end{array}$ & $\begin{array}{l}\text { Double- } \\
\text { blind RCT } \\
\text { (1 month) }\end{array}$ & $\begin{array}{l}100 \text { units of IA- } \\
\text { BoNT/A in } 1 \mathrm{ml} \text { of } \\
\text { saline plus } 1 \mathrm{ml} \\
\text { of } 2 \% \text { lidocaine } \\
\text { (treatment group; } \\
\mathrm{n}=21 \text { ), } \\
\text { Single injection of } \\
\text { IA-saline plus } 1 \mathrm{ml} \\
\text { of } 2 \% \text { lidocaine } \\
\text { (placebo group; } \\
\mathrm{n}=22 \text { ) }\end{array}$ & $\begin{array}{l}\text { BoNT: } 72 \mathrm{yrs}^{2} \\
\text { PL: } 70 \mathrm{yrs}^{3}\end{array}$ & $\begin{array}{l}\text { Pain on VAS } \\
\text { Drop-out due to } \\
\text { treatment failure } \\
\text { Short Form } 36 \\
\text { Short form McGill } \\
\text { Pain } \\
\text { Shoulder pain } \\
\text { and disability } \\
\text { index (SPADI) }\end{array}$ & $\begin{array}{l}\text { Significantly greater reduction in } \\
\text { VAS pain scores in IA-BoNT/A } \\
(2.4) \text { vs. placebo }(0.8) \text { group } \\
(p=0.02) \\
\text { Higher proportion dropped out at } \\
1 \text { month from placebo }(45 \%) \text { than } \\
\text { IA-BoNT/A (19\%) }(p=0.13) \\
\text { SF-36 scores improved } \\
\text { significantly more in IA-BoNT/A } \\
\text { vs. placebo in } 5 / 8 \text { subscales } \\
\text { ( } p \text { ranging from 0.04-0.001) } \\
\text { McGill affective dimension scores } \\
\text { were significantly greater in IA- } \\
\text { BoNT/A vs. placebo group } \\
\text { ( } p=0.047 \text { ) } \\
\text { Trend towards significance in } \\
\text { SPADI disability scores ( } p=0.083 \text { ) } \\
\text { No significant differences in active } \\
\text { flexion, active abduction, SPADI } \\
\text { pain and total and McGill sensory } \\
\text { and total scores. }\end{array}$ \\
\hline $\begin{array}{l}\text { Boon } \\
\text { et al. }{ }^{73}\end{array}$ & $\begin{array}{l}\mathrm{N}=60 \text { (60 } \\
\text { painful knees) } \\
(25 \mathrm{M} / 35 \mathrm{~F}) \\
6-10 \text { years }\end{array}$ & $\begin{array}{l}\text { Double- } \\
\text { blind RCT } \\
\text { (8-weeks) }\end{array}$ & $\begin{array}{l}\text { IA-BoNT/A at } 2 \\
\text { doses } 100 \text { units } \\
(n=20) \text { or } 200 \text { units } \\
(n=20) \\
\text { IA-corticosteroid } \\
\text { injection with } \\
40 \text { mg of } \\
\text { methylprednisolone } \\
\text { acetate }(n=20)\end{array}$ & $\begin{array}{l}\text { BoNT } 100 \\
\text { units: } 64 \text { yrs }^{13} \\
\text { BoNT } 200 \\
\text { units: } 61 \text { yrs }^{9} \\
\text { Corticosteroid: } \\
61 \text { yrs }^{10}\end{array}$ & $\begin{array}{l}\text { Pain on VAS } \\
\text { Western Ontario } \\
\text { McMaster } \\
\text { Osteoarthritis } \\
\text { Index (WOMAC) } \\
\text { 40-m walk test } \\
\text { Short Form } 36\end{array}$ & $\begin{array}{l}\text { Significant reduction in VAS pain } \\
\text { scores with injection in each of } \\
\text { the } 3 \text { groups, but no significant } \\
\text { difference between groups. 2-point } \\
\text { reduction in VAS pain scores of } \\
\text { participants in } 60 \% \text { BoNT ( } 100 \\
\text { units), } 26 \% \text { in BoNT (200 units) } \\
\text { and } 42 \% \text { in corticosteroid group } \\
(p=0.10) \text {. } \\
\text { Significant reduction in WOMAC } \\
\text { pain, function and stiffness scales } \\
\text { and } 40 \text { min walk with injection } \\
\text { in each of the } 3 \text { groups, but no } \\
\text { significant difference between } \\
\text { groups. } \\
\text { SF-36 scores did not change } \\
\text { significantly from baseline in any } \\
\text { of the } 3 \text { groups at } 8 \text { weeks, with } \\
\text { the exception of the SF-36 pain } \\
\text { index, which improved in the high- } \\
\text { dose BoNT-A group. }\end{array}$ \\
\hline $\begin{array}{l}\text { Mahowald } \\
\text { et al. } .^{74}\end{array}$ & $\begin{array}{l}N=42 \\
\text { Refractory } \\
\text { chronic painful } \\
\text { knees; pain } \\
\text { duration not } \\
\text { provided }\end{array}$ & $\begin{array}{l}\text { Double- } \\
\text { blind RCT, } \\
\text { 1-month }\end{array}$ & $\begin{array}{l}100 \text { units of } \\
\text { BoNT/A) in } 1 \mathrm{ml} \\
\text { of saline plus } 1 \mathrm{ml} \\
\text { of } 2 \% \text { lidocaine } \\
\text { (treatment group, } \\
n=21 \text { ) } \\
\text { Single injection of } \\
\text { IA-saline plus } 1 \mathrm{ml} \\
\text { of } 2 \% \text { lidocaine } \\
\text { (placebo group, } \\
n=21 \text { ) }\end{array}$ & $N / A$ & $\begin{array}{l}\text { McGill Pain } \\
\text { VAS pain } \\
\text { WOMAC }\end{array}$ & $\begin{array}{l}\text { Changes in the McGill Pain } \\
\text { Inventory joint pain scores were } \\
\text { similar in the IA-BoNT/A and } \\
\text { placebo groups at one month. } \\
(-4.7, p=0.048 \text { in IA-BoNT/A } \\
\text { group and }-5.6, p=002 \text { in the } \\
\text { placebo group). } \\
\text { At } 3 \text { months change in VAS pain } \\
\text { was significant only in the IA- } \\
\text { BoNT/A treatment group (-4.2, } \\
p=0.002 \text { in the IA-BoNT/A group } \\
\text { and }-4.6, p=0.09 \text { in the placebo } \\
\text { group). }\end{array}$ \\
\hline
\end{tabular}

RCT, randomized controlled trial; BoNT, botulinum toxin; PL, placebo; SQ, subcutaneous; VAS, Visual Analog Scale; SD, standard deviation; IA, intra-articular. 
type A (IA-BoNT/A) reconstituted in 1cc of saline plus $1 \mathrm{ml}$ of $2 \%$ lidocaine (treatment group; $\mathrm{n}=21$ ) or a single injection of IA-saline plus $1 \mathrm{ml}$ of $2 \%$ lidocaine (placebo group; $\mathrm{n}=22$ ). Patients were enrolled in the study if they had chronic knee pain of 4.5 or more on a 0-10 NRS pain scale for at least 6-months, evidence of radiographic OA, had a failed response to oral analgesics/anti-inflammatory drugs and IA-corticosteroid injections, and were not candidates for shoulder joint replacement surgery. Patients were excluded if they were currently using aminoglycoside antibiotics, curare-like agents, or other agents that might interfere with neuromuscular function; had shoulder joint malignancy, a prosthetic shoulder joint or planned shoulder joint surgery in the next 6 months; prior botulinum toxin injection into the index shoulder joint; had disorders of neuromuscular function including myasthenia gravis, EatonLambert syndrome, amyotrophic lateral sclerosis; known allergy/ sensitivity to study medications; a history of recent or ongoing alcohol or drug abuse, uncontrolled systemic disease; or were pregnant, breast feeding or planning pregnancy during the study period. The study had $>80 \%$ power to detect 1.5 unit difference in pain NRS scale between intervention and placebo.

At a 1-month follow-up or later, if patients did not experience any reduction in pain severity (due to inefficacy of the treatment), they were given the option to drop out of the randomized phase of the study, and request the second unblinded injection with 100 units of IA-BoNT/A, which led to the beginning of an open-label phase. The published paper reported the results from the 1-month doubleblind portion of the study ${ }^{70}$.

36 patients with 43 painful shoulder joints were randomized. Mean age was $>70$ years, $95 \%$ were men, $>85 \%$ had OA as the underlying diagnosis, mean shoulder pain duration was 8-11 years, comorbidity index was high, at least $50 \%$ had been treated each with narcotics or non-steroidal anti-inflammatory drugs (NSAIDs), and all had failed previous IA-corticosteroid injections.

Reductions in shoulder pain severity were significantly greater in the IA BoNT/A group compared to the IA placebo group at 1 month ( -2.4 vs. -0.8 unit reductions NRS respectively, $\mathrm{p}=0.014$; primary outcome). $61 \%$ of patients in the IA BoNT/A group experienced clinically meaningful pain relief (defined as a $30 \%$ or 2-point reduction previously ${ }^{71,72}$ ) at 1 month compared with $36 \%$ in the placebo group $(\mathrm{p}=0.22)$.

Several secondary outcomes were significantly better in the IABoNT/A versus the IA-placebo group. Quality-of-life improvements were significantly greater in the BoNT/A group versus the placebo group for five of the eight short form-36 (SF-36) subscales at 1-month, namely bodily pain, role physical, energy/vitality, role emotional and mental health (p-values ranging from 0.04 to 0.001 ). Improvements in quality of life exceeded the clinically meaningful threshold of 10-points for all 5 SF-36 subscales in IA-BoNT/A group versus as opposed to only 1 subscale in the IA-placebo group. McGill affective pain dimension improved significantly more in BoNT/A compared to placebo at 1 -month $(\mathrm{p}=0.047)$. Other secondary measures showed a trend in improvements, but were not statistically significantly different between treatment groups. The
Shoulder Pain and Disability Index (SPADI) showed a trend towards greater improvement in BoNT/A versus placebo group $(p=0.0826)$. Treatment-failure after 1 month, defined as a drop-out from the blinded phase due to inefficacy and request for an active treatment injection, was 2.5-times higher in the placebo vs. the BoNT/A group; $45 \%(10 / 22)$ vs. $19 \%(4 / 21 ; p=0.128)$ respectively. $61 \%$ in BoNT/A group experienced clinically meaningful pain relief at 1 month (a 2-point or 30\% reduction in pain severity on the visual analogue pain scale (VAS)) compared to $36 \%$ in the placebo group $(\mathrm{p}=0.22)$.

The change in pain severity was influenced by baseline SPADI disability. In those patients with a higher SPADI disability score (>61.3), the decrease in VAS pain ratings at 1 month was significantly greater in the BoNT/A group (a 3.6 reduction) compared with the placebo $(0.5 ; \mathrm{p}=0.015)$. On the other hand, in patients with lower SPADI disability score $(\leq 61.3)$, no significant difference was observed in VAS pain severity reduction between BoNT/A (a 1.9 reduction) and placebo groups (a 1.6 reduction; $\mathrm{p}=0.73$ ).

Overall adverse events were similar in IA-BoNT/A and IA-placebo groups. No significant difference in serious adverse events was noted. Common adverse events such as dry mouth, flu-like symptoms, dizziness etc. were not statistically significantly different between treatment groups in this small study, powered for efficacy, but not safety outcomes.

\section{Refractory knee joint pain: 2 RCTs of intra-articular BoNT/A} (IA-BoNT/A)

Comparison of IA-BoNT/A to IA-corticosteroid. Boon et al. compared IA-BoNT/A to IA-corticosteroids in patients with radiographic and clinical knee OA in an $\mathrm{RCT}^{73}$ (Table 1). In a singlecenter, prospective double-blind RCT, patients were randomized to one of three treatments - a single injection of 100 units ( 2 standard doses) of IA-BoNT/A (20 patients), 200 units (20 patients) or an IA-corticosteroid injection with $40 \mathrm{mg}$ of methylprednisolone acetate (20 patients), into the painful knee joint. Patients were eligible for the study if they were adults $\geq 40$ years that had both symptomatic knee OA with knee pain severity of $\geq 6$ on a 10 -point NRS scale that interfered with function most days of the week and Kellgren grade II or III tibiofemoral knee OA identified by plain radiographs. Patients were excluded if they had Kellgren grade I or IV tibiofemoral knee OA, inflammatory arthritis (such as rheumatoid arthritis, gout or pseudogout), reconstructive surgery on the affected knee, body mass index $>35 \mathrm{~kg} / \mathrm{m}^{2}$, recent IA-corticosteroid or hyaluronic acid injection (last 3-months), a clinically unstable medical or psychiatric condition or history of neuromuscular disease, aminoglycoside or curare-like agents use or severe peripheral neuropathy.

The primary outcome was VAS (0-10) pain scores at 8-weeks postinjection (rated using a $10 \mathrm{~cm}$ line). Secondary outcomes included lower extremity pain and function assessment using the Western Ontario McMaster Universities Arthritis Index (WOMAC), quality of life assessment using the SF-36, patient global assessment and time taken for a 40-meter self-paced walk (in seconds). The study was powered to detect a $2 \mathrm{~cm}$ reduction in a VAS pain rating within each group compared to baseline scores. Non-responders were 
allowed to request a second injection at 8-weeks during face-to-face clinic visit after the blinded injection. Additional follow-up assessments were done at 12 and 26 weeks using mailed questionnaires.

Baseline characteristics were similar in the three groups. Patients had a mean age of 61-64 years, body mass index $28-31 \mathrm{~kg} / \mathrm{m}^{2}$, symptom duration ranging from 6-10 years and 50-65\% were women. Patients had tried multiple modalities for knee pain relief in the past, including: $70-80 \%$ had tried IA-corticosteroid injections, 35-50\% had tried IA-hyaluronic acid injections, 55-65\% had tried acetaminophen, 75-90\% had tried corticosteroids and $45-80 \%$ had tried physical therapy. All 60 patients (35 women and 25 men) completed the 8-week follow-up.

VAS pain scores decreased from $6.4 \pm 1.8 \mathrm{~cm}$ to $5.4 \pm 2.3 \mathrm{~cm}(\mathrm{p}=0.15$; $22 \%$ reduction) in the IA-corticosteroid group. In the 100-unit IABoNT/A (low dose) group, pain severity decreased significantly from $6.6 \pm 1.9 \mathrm{~cm}$ to $4.5 \pm 2.2 \mathrm{~cm}(\mathrm{p}=0.01 ; 28 \%$ reduction $)$; and in the 200 units (high-dose) IA-BoNT/A group decreased from $6.6 \pm 1.4 \mathrm{~cm}$ to $5.9 \pm 2.4 \mathrm{~cm}(\mathrm{p}=0.15 ; 26 \%$ reduction $)$. A $2 \mathrm{~cm}$ reduction in VAS pain scores, which is considered a clinically meaningful reduction in pain $^{71,72}$, was reported by $42 \%$ in the IA-corticosteroid group, $60 \%$ in 100-unit IA-BoNT/A group and $26 \%$ in the 200 -unit IABoNT/A group ( $p=0.10$ for comparison between three groups; differences between 100 and 200 units not significant). Secondary outcomes including WOMAC pain scores, function and stiffness and self-paced 40 meter walk time improved significantly within each of the three groups at 8 -weeks, compared to baseline $(\mathrm{p}<0.05$ for each; Table 1). However, there were no significant differences for WOMAC scores between groups at 8-weeks. SF-36 scales did not improve significantly in any group, except in the mental health subscale score at 8-weeks in the IA-BoNT/A 200 unit group (Table 1). At the 8-week follow-up $65 \%$ in the IA-corticosteroid group, $75 \%$ in 100-unit IA-BoNT/A group and 70\% in 200-unit IABoNT/A group said that they would have the treatment again. Seventeen patients withdrew from the study at the 8-week follow-up requesting re-injection and an additional 11 patients did not complete the 6-month follow-up questionnaire. For the patients remaining in the trial, the reduction in VAS pain was sustained at 12-weeks for both 100- and 200-unit IA-BoNT/A and at 12 and 26 weeks in the 100-unit IA-BoNT/A group, but not in the IA-corticosteroid group. No deaths, anaphylactic reaction or septic arthritis were reported in any group, strength testing did not reveal any significant changes at any time-point in treatment groups and none of the common adverse events were significantly different between groups in this small study, powered for efficacy, but not safety assessments.

Comparison of IA-BoNT/A to IA-placebo. In a recent review article, Mahowald et al. summarized the results of an RCT comparing a single injection of 100 units of BoNT/A reconstituted in $1 \mathrm{ml}$ of saline plus $1 \mathrm{ml}$ of $2 \%$ lidocaine (treatment group) to a single injection of IA-saline plus $1 \mathrm{ml}$ of $2 \%$ lidocaine (placebo group) in patients with refractory knee pain due to knee $\mathrm{OA}^{74}$ (Table 1). Patients were enrolled in the study if they had chronic knee pain of 4.5 or more on the NRS pain scale for at least 3 months, evidence of radiographic OA, had received no benefit from oral analgesics/ anti-inflammatory drugs, IA-corticosteroid or IA-hyaluronic acid injections, and were not candidates for joint replacement surgery.
Exclusion criteria were the same as those stated in the shoulder RCT described in the section earlier ${ }^{75}$. We considered the patient's report of knee pain relief 5-10 minutes after the injection and/or aspiration of joint fluid as a surrogate for an accurate intra-articular placement of the needle.

Forty-two patients were randomized to either a IA-BoNT/A or IA-placebo group. At 1-month, McGill pain scores decreased significantly in both the IA-BoNT/A (4.7, p = 0.048) and IA-placebo groups $(5.6, \mathrm{p}=0.02)$. However, at 3 months the decrease in pain was significant only in the IA-BoNT/A $(4.2, \mathrm{p}=0.002)$, but not in the placebo group $(4.6, \mathrm{p}=0.09)$.

Due to a differential treatment effect evident on scatter plots, patients were stratified by baseline NRS pain scale scores into moderate (4.5-6.9) or severe (7 or higher) pain for exploratory analyses. In the severe knee pain group, significant changes in McGill sensory, affective and total pain scores were noted in the IA-BoNT/A, but not in the placebo group (Table 1).

\section{Summary and study limitations: OA knee and shoulder pain (osteoarticular pain)}

In summary, three RCTs and three non-randomized studies indicate that a single intra-articular injection of botulinum toxin is associated with a clinically meaningful reduction of pain and an improvement of function in patients with refractory joint pain due to osteoarthritis or other underlying arthritic-conditions. The non-randomized studies have the limitations of bias, lack of a placebo arm and over-amplification of the treatment effect. All three randomized studies had small samples, short follow-up, and tested a single dose of botulinum toxin. Hence, it is not known if the toxin is effective for long-term pain relief and what the most optimal dose is. Also, due to small sample size, these studies could not provide data with regards to who are the best candidates for this injection. Therefore, larger studies are needed to assess the most effective dose, the longterm safety of intra-articular injections and to define as to which patients might be the best candidates for this treatment option.

\section{Tennis elbow}

Non-randomized studies

In an open-label case series of 14 patients with "treatment-resistant" tennis elbow, Moore and colleagues injected 20-40 units of BoNT/A into the extensor digitorum communis and found $>50 \%$ pain relief in $9 / 14$ and complete pain relief in $4 / 14$ patients during the 6-8 month follow-up ${ }^{76}$. Pain relief began by 2 weeks in 10 patients, 3 weeks in one and after 1 month in two patients.

\section{RCTs Comparing BoNT to placebo or surgery}

Hayton et al. studied 40 patients with refractory tennis elbow pain with a duration of over 6 months, who had experienced no pain relief from $\geq 1$ corticosteroid injections and a full course of physiotherapy ${ }^{77}$ (Table 2). Patients were randomized to either 50 units of botulinum toxin type A (Allergan; $n=19$ ) or normal saline placebo $(2 \mathrm{ml} ; \mathrm{n}=21$ ) injected $5 \mathrm{~cm}$ distal to the area of maximal tenderness at the lateral epicondyle ${ }^{77}$ (Table 2). There were no statistically significant differences in pain between the botulinum toxin and placebo groups at 3 months after the injection (difference of 1.1 between groups, $\mathrm{p}=0.54$ ), grip strength (difference of $0.57 \mathrm{~kg}$ between 
Table 2. Efficacy outcomes of botulinum toxin in tennis elbow in randomized controlled trials.

\begin{tabular}{|c|c|c|c|c|c|c|c|}
\hline Study & $\begin{array}{l}\text { \# Patients } \\
\text { (male/ } \\
\text { female) }\end{array}$ & $\begin{array}{l}\text { Study type } \\
\text { (duration) }\end{array}$ & Groups & $\begin{array}{l}\text { Mean age in } \\
\text { years (SD) }\end{array}$ & $\begin{array}{l}\text { Mean pain } \\
\text { duration } \\
\text { months (SD) }\end{array}$ & $\begin{array}{l}\text { Primary } \\
\text { outcomes }\end{array}$ & Main result - efficacy \\
\hline $\begin{array}{l}\text { Wong } \\
\text { et al. }{ }^{79}\end{array}$ & $\begin{array}{l}N=60 \\
(49 \mathrm{M} / 11 \mathrm{~F})\end{array}$ & $\begin{array}{l}\text { RCT, } \\
\text { Double-blind } \\
\text { (3-months) }\end{array}$ & $\begin{array}{l}\text { Single } \\
\text { injection of } \\
60 \text { units of } \\
\text { IA-BoNT/A } \\
\text { (Dysport, } \\
n=30) \\
\text { Saline } \\
\text { placebo in } \\
\text { SQ tissue } \\
\text { and muscle } \\
(n=30)\end{array}$ & $\begin{array}{l}\text { BoNT: } 46 \mathrm{yrs}^{9} \\
\mathrm{PL}: 44 \mathrm{yrs}^{6}\end{array}$ & $\begin{array}{l}\text { BoNT: } 12^{9} \\
\text { PL: } 19^{21}\end{array}$ & $\begin{array}{l}\text { VAS }(0-100 \\
\mathrm{mm}) \text { at } 4-\text { and } \\
12-\text { weeks }\end{array}$ & $\begin{array}{l}\text { BoNT: VAS pain } 25.3 \text { at } 4 \text { weeks; } \\
23.5 \text { at } 12 \text { weeks } \\
\text { PL: VAS pain } 50.5 \text { at } 4 \text { weeks; } \\
43.5 \text { at } 12 \text { weeks } \\
\text { Differences significant at both } \\
4 \text { weeks }(p<0.0001) \text { and } 12 \\
\text { weeks }(p=0.0006)\end{array}$ \\
\hline $\begin{array}{l}\text { Keizer } \\
\text { et al. }{ }^{80}\end{array}$ & $\begin{array}{l}N=40 \\
(19 M / 21 F)\end{array}$ & $\begin{array}{l}\text { Randomized, } \\
\text { not blinded, } \\
\text { (24-months) }\end{array}$ & $\begin{array}{l}\text { Surgical } \\
\text { release } \\
(n=20) \\
1-2 \text { injections } \\
\text { of } 30-40 \text { units } \\
\text { BoNT }(n=20)\end{array}$ & $\begin{array}{l}\text { All patients: } \\
43 \text { yrs (range, } \\
25-72 \text { yrs) }\end{array}$ & $\begin{array}{l}\text { All patients: } \\
11 \text { (range, } \\
6-48 \text { ) }\end{array}$ & $\begin{array}{l}\text { Pain, range } \\
\text { of motion, } \\
\text { sick leave, } \\
\text { Modified } \\
\text { scoring } \\
\text { system } \\
\text { of pain, } \\
\text { function, } \\
\text { tenderness, } \\
\text { and } \\
\text { satisfaction }\end{array}$ & $\begin{array}{l}\text { No difference in pain between } \\
\text { groups } \\
\text { Range of motion significantly } \\
\text { better in BoNT compared } \\
\text { to surgery group at } 3 \text { and } 6 \\
\text { mths; no difference at } 12 \text { or } 24 \\
\text { months. } \\
\text { Sick leave lower in surgery } \\
\text { group versus BoNT group at } \\
3 \text { months ( } p=0.01 \text { ), but no } \\
\text { difference at } 6,12 \text { and } 24 \\
\text { months } \\
\text { Overall score was similar in two } \\
\text { groups at } 3,6,12 \text { and } 24 \text { mths }\end{array}$ \\
\hline $\begin{array}{l}\text { Hayton } \\
\text { et al. }{ }^{77}\end{array}$ & $\begin{array}{l}N=40 \\
(21 \mathrm{M} / 19 \mathrm{~F})\end{array}$ & $\begin{array}{l}\text { Double- } \\
\text { blind RCT } \\
\text { (3-months) }\end{array}$ & $\begin{array}{l}\text { One } 50 \text { unit } \\
\text { injection } \\
\text { of BoNT/A } \\
(n=19) \\
\text { Saline } \\
\text { placebo } \\
\text { intramuscular } \\
5 \mathrm{~cm} \text { distal } \\
\text { to area of } \\
\text { maximum } \\
\text { tenderness } \\
(n=21)\end{array}$ & $\begin{array}{l}\text { All patients: } \\
47 \text { yrs (range, } \\
35-71 \text { yrs) }\end{array}$ & $\begin{array}{l}\text { All patients: } \\
11 \text { (range, } \\
6-48 \text { ) }\end{array}$ & $\begin{array}{l}\text { Pain, grip } \\
\text { strength, } \\
\text { Short Form-12 }\end{array}$ & $\begin{array}{l}\text { Differences in pain scores were } \\
\text { not significant at } 3 \text { months } \\
\text { No significant differences in } \\
\text { grip strength or SF- } 12 \text { scores } \\
\text { between groups at } 3 \text { months }\end{array}$ \\
\hline $\begin{array}{l}\text { Lin } \\
\text { et al. }{ }^{81}\end{array}$ & $\begin{array}{l}\mathrm{N}=19 \\
\text { elbows in } \\
16 \text { patients } \\
(9 \mathrm{M} / 8 \mathrm{~F})\end{array}$ & $\begin{array}{l}\text { Double- } \\
\text { blind RCT } \\
\text { (3-months) }\end{array}$ & $\begin{array}{l}\text { One } 50 \text { unit } \\
\text { injection of } \\
\text { BoNT/A }(\mathrm{n}=8) \\
\text { Coticosteroid } \\
\text { injection } \\
\text { ( } 40 \mathrm{mg} \\
\text { triamcinolone } \\
\text { acetonide)_- } \\
\text { into extensor } \\
\text { carpi radialis } \\
\text { brevis muscle } \\
\text { near the } \\
\text { common } \\
\text { origin of wrist } \\
\text { and finger } \\
\text { extensors } \\
\text { ( } \mathrm{n}=9 \text { ) }\end{array}$ & $\begin{array}{l}\text { BoNT: Mean } \\
45.9(7.8) \\
\text { years } \\
\text { Corticosteroid: } \\
44.6(11.0) \\
\text { years }\end{array}$ & $\begin{array}{l}\text { Symptoms } \\
\text { <3-months: } \\
\text { BoNT: } 8 \\
\text { Corticosteroid: } 8\end{array}$ & $\begin{array}{l}\text { Visual Analog } \\
\text { Scale pain, } \\
\text { grip strength, } \\
\text { and World } \\
\text { Health } \\
\text { Organization } \\
\text { Quality of } \\
\text { Life Brief } \\
\text { Questionnaire }\end{array}$ & $\begin{array}{l}\text { Corticosteroid injection was } \\
\text { significantly superior to } \\
\text { Botulinum toxin injection for } \\
\text { improvement in pain scores at } \\
\text { 4-weeks. } \\
\text { Grip strength was lower in } \\
\text { botulinum toxin injection versus } \\
\text { corticosteroid injection } \\
\text { No significant differences in SF- } \\
12 \text { scores between groups. }\end{array}$ \\
\hline
\end{tabular}




\begin{tabular}{|c|c|c|c|c|c|c|c|}
\hline Study & $\begin{array}{l}\text { \# Patients } \\
\text { (male/ } \\
\text { female) }\end{array}$ & $\begin{array}{l}\text { Study type } \\
\text { (duration) }\end{array}$ & Groups & $\begin{array}{l}\text { Mean age in } \\
\text { years (SD) }\end{array}$ & $\begin{array}{l}\text { Mean pain } \\
\text { duration } \\
\text { months (SD) }\end{array}$ & $\begin{array}{l}\text { Primary } \\
\text { outcomes }\end{array}$ & Main result - efficacy \\
\hline $\begin{array}{l}\text { Placzek } \\
\text { et al. }\end{array}$ & $\begin{array}{l}\mathrm{N}=132 \\
\text { patients of } \\
\text { whom } 130 \\
\text { completed } \\
\text { the study } \\
(61 \mathrm{M} / 69 \mathrm{~F})\end{array}$ & $\begin{array}{l}\text { Double- } \\
\text { blinded RCT } \\
\text { (18 weeks) }\end{array}$ & $\begin{array}{l}\text { One } 60 \text { unit } \\
\text { injection } \\
\text { of BoNT/A } \\
(n=70) \\
\text { Saline } \\
\text { injection } \\
(n=62)\end{array}$ & $\begin{array}{l}\text { BoNT: Mean } \\
47.4(8.7) \\
\text { years } \\
\text { Saline: } 46.9 \\
\text { (9.4) years }\end{array}$ & $\begin{array}{l}\text { BoNT: } 8 \\
\text { months } \\
\text { Saline: } 10 \\
\text { months }\end{array}$ & $\begin{array}{l}\text { Pain, strength } \\
\text { of extension } \\
\text { of finger and } \\
\text { wrist, grip } \\
\text { strength, } \\
\text { patient global } \\
\text { assessment } \\
\text { or response, } \\
\text { pain } \\
\text { medication } \\
\text { use }\end{array}$ & $\begin{array}{l}\text { Botulinum toxin was significantly } \\
\text { better than saline in pain relief } \\
\text { by week 2, and improvements } \\
\text { sustained through 18-weeks } \\
\text { Patient global assessment of } \\
\text { satisfaction and MD global } \\
\text { assessments were significantly } \\
\text { better in Botulinum toxin vs. } \\
\text { saline group. } \\
\text { No significant differences in grip } \\
\text { strength were noted between } \\
\text { groups, although it improved in } \\
\text { both groups. } \\
\text { Extension of third finger was } \\
\text { decreased significantly in } \\
\text { botulinum toxin group at } 2 \\
\text { weeks, persisted till } 14 \text { weeks, } \\
\text { but ceased at } 18 \text { weeks. No } \\
\text { other significant differences in } \\
\text { side effects were noted between } \\
\text { groups. }\end{array}$ \\
\hline
\end{tabular}

RCT, randomized controlled trial; BoNT, botulinum toxin; PL, placebo; SQ, subcutaneous; VAS, Visual Analog Scale; SD, standard deviation.

groups, $\mathrm{p}=0.90$ ), or quality of life measured by the Short Form12 physical (difference of 6.24 points between groups, $\mathrm{p}=0.16$ ) and mental (difference of 4.26 points between groups, $\mathrm{p}=0.42$ ) component summary scores. Twelve of the 18 patients in the BoNT group had a transient extensors lag of the long finger at 1-weeks that disappeared 3-months after the injection; none reported this in the placebo group. The 1-point difference in pain scores between the BoNT and placebo group in this study is similar to that noted in studies of joint pain ${ }^{70,73,78}$, however, the larger standard deviation likely led to this difference being non-significant in this case.

In another study by Wong et al. 60 patients experiencing tennis elbow pain for 3 months or longer were randomized to either a single injection of 60 units of botulinum toxin A (Dysport; Ipsen) or saline placebo injections into soft tissue and muscle $1 \mathrm{~cm}$ from the lateral epicondyle ${ }^{79}$ (Table 2). Patients were treatment-naive with no prior local injections. Patients were followed for 12 weeks in a double-blinded multicenter study. The mean age was 45 years, 49 were women and symptom duration was between 12 and 19 months in the two groups. Pain on a VAS scale $(0-100 \mathrm{~mm})$ decreased significantly more in the active treatment group $(65.5 \mathrm{~mm}$ at baseline to $25.3 \mathrm{~mm}$ at week 4 and $23.5 \mathrm{~mm}$ at week 12$)$ than placebo $(66.2 \mathrm{~mm}$ at baseline to $50.5 \mathrm{~mm}$ at week 4 and $43.5 \mathrm{~mm}$ at week 12). The differences between groups were statistically significant at both week $4(\mathrm{p}<0.001)$ and week $12(\mathrm{p}=0.006)$. Mild weakness in finger extension at 4 weeks was seen in 10 patients in the BoNT/A group versus 6 patients in the saline group. Four patients in the Botulinum group had paresis of the fingers at 4 weeks (in one patient this persisted to week 12) compared to none in the placebo group, but grip strength was similar in both groups at the two time points.

Another randomized study compared 1 to 2 injections of 30-40 units of Botulinum toxin type A (Allergan Inc.) into the wrist extensor with the surgical release of the extensor origin of the extensor carpi radialis brevis tendon ${ }^{80}$ (Table 2). Forty patients with refractory chronic tennis elbow pain (average duration of symptoms $\sim 10$ months) were randomized, 20 to each treatment. The mean age of the patients was 43 years, average symptom duration was 11 months (range 6-48 months), and 21 were women. They found no differences between the groups with regards to pain and grip strength up to 2 years of follow-up, while minor differences were noted at shorter follow-up periods. At 1 year, $65 \%$ of patients in the Botulinum toxin group and $75 \%$ in the operative group had good to excellent results (based on a validated composite scale with pain and patient satisfaction items). Limitations of the study included the lack of description of outcomes and the lack of a priori designation of outcomes as primary versus secondary.

In a double-blinded RCT, Lin et al. compared botulinum type A to corticosteroid injection for the treatment of acute and subacute tennis elbow of 16 patients with 19 affected elbows ${ }^{81}$. Compared to corticosteroid, botulinum type A injection was associated with less pain reduction $(\mathrm{p}=0.02)$ but a greater decrease in grip strength $(p=0.01)$ at 4 -weeks post-injection. With the progression of time since injection, the amount of pain reduction increased in the botulinum toxin group, but decreased in corticosteroid group, though this difference was not statistically significant. No significant differences between groups were noted in quality of life. Thus, corticosteroid was superior to botulinum toxin type $\mathrm{A}$ in relieving pain in tennis elbow at 4-weeks after injection.

A double-blinded RCT comparing a single injection of 60 units of botulinum toxin A (Dysport) compared to saline was performed in 132 patients with chronic tennis elbow in a multicenter study ${ }^{82}$. The site of injection was the painful origin of the forearm extensor muscles and patients were followed up to 18 weeks. Compared to placebo, patients in the botulinum toxin A group had a significant improvement in pain as early as the second week after injection ( $\mathrm{p}=$ 0.003). Both subjective general assessment of response to injection as well as blinded physician assessments also showed improvement 
in botulinum toxin A group, compared with the placebo group, both at six weeks $(p=0.001)$ and at 18 weeks $(p=0.001)$. Both groups experienced a consistent increase in fist closure strength, but there was no significant difference between groups. The extension of the third finger was observed to be significantly weakened at two weeks in the botulinum toxin A group and not saline control group, but this complication had completely resolved at 18 weeks.

\section{Summary and study limitations: tennis elbow}

In summary, results from five RCTs of patients with tennis elbow indicate that botulinum toxin may be effective (two of the three RCTs were positive; three RCTs were negative but had a small sample size), in at least some patients with tennis elbow; however, given that 3 of the 5 trials had negative results, this needs further study. An important observation was that the studies with the largest sample sizes of 60 and 132 was positive, compared to the three negative studies that had smaller sample sizes (40, 40 and 16). A smaller sample size may have made the study underpowered and led to negative results. A short follow up period is another limitation of these RCTs. The studies differed in patient population (patients with non-refractory vs. refractory disease), duration of disease ( $>3$ months vs. $>6$ months vs. 10 months), site of injection $(1 \mathrm{~cm}$ vs. $5 \mathrm{~cm}$ from the lateral epicondyle or direct into the wrist extensor) and the dosage of preparation used (60 units of Dysport vs. 50 units of Botox vs. 30-40 unit injections of Botox) in the three RCTs respectively.

\section{Temporomandibular joint (TMJ) pain}

\section{Non-randomized studies}

In an open-label study of 41 patients with painful hyperactivity of the masticatory muscles, 200 units of BoNT/A (Dysport) was injected intramuscularly, with 8 conducted under electromyographic guidance $)^{83}$. The patients in this study had not gained pain relief from conservative treatment after 3 to 12 months of symptom duration. In 29 cases, only one treatment was administered. The majority of the injections were administered intraorally. Patients were observed for up to 12 months. $80 \%$ of patients reported an improvement in pain. The mean pain severity decreased from 6.4 to 3.5 on the $0-10 \mathrm{~cm}$ VAS scale. Thirteen patients experienced a "major improvement" as evident by the disappearance of pain. Relief lasted 3-12 months during the observation period for most individuals; only 7 patients requested re-injection. One patient experienced temporary speech impairment and swallowing difficulty post-injection, which had completely reversed after $2-5$ weeks.

In an open-label study, 46 patients who had experienced TMJ pain for a median duration of 96 months were injected with 50 units of botulinum toxin $\mathrm{A}$ in each masseter muscle and 25 units in each temporalis muscles under electromyographic guidance ${ }^{84}$. Patients were followed up to 8 weeks. The mean age was 41 years and 39 were women. Comparing pre-injection to 8-week post-injection assessments, a significant improvement was noted in the pain VAS from a median of 8 to 5 , functional disability index scores dropped from 5.3 to $3.9 \mathrm{~mm}$, tenderness to palpation reduced from 15.5 to $6 \mathrm{~mm}$ and jaw opening extent improved from 29.5 to $34.5 \mathrm{~mm}$ ( $\mathrm{p}<0.05$ for assessments). No subjects reported worsening of their condition or any side effects after the injection.
In another study, 15 patients with temporomandibular disorder received 150 units of BoNT/A with 50 units in each masseter and 25 units in each temporalis muscle bilaterally ${ }^{85}$. The mean age was 39 years and 13 were women with a mean symptom duration of 10 years. Compared to pre-injection, at 8 weeks post-injection, a significant improvement was noted in patients; mean pain VAS scores dropped from 7.3 to 4 , functional disability index scores reduced from 5.5 to 3.1 , tenderness to palpation scores improved from 17 to 7.6 and jaw opening extent increase from 27 to $34 \mathrm{~mm}$ ( $\mathrm{p}<0.05$ for assessments).

One RCT in patients with facial pain and temporomandibular disorder

In a single-blinded randomized study, 90 patients with chronic facial pain caused by hyperactivity of the masticatory muscles, received intramuscular injections of 35 mouse units (based on the amount required for a lethal dose in mice) of botulinum toxin $\mathrm{A}$ (Allergan; $n=60)$ or placebo $(n=30)$ in both masticatory muscle ${ }^{86}$ (Table 3). The patients in the study had experienced no relief from conservative treatment after 3 to 34 months of use. A significantly greater reduction in 0-10 VAS pain scores was noted in the Botulinum toxin (a 3.2 unit decrease) compared with the placebo group (a 0.4 unit decrease $)(\mathrm{p}<0.01)$ was found at a follow-up conducted between 1-3 months. A greater proportion of patients in the BoNT/A group had $\geq 2$-point improvement in VAS pain scores during the follow-up. One patient experienced temporary paralysis of facial expression muscles and swallowing difficulty post-injection, which resolved after 4 weeks. No speech impairment or systemic botulism was reported.

\section{Summary and study limitations: temporomandibular pain disorders}

In summary, the evidence for efficacy of intramuscular injections of botulinum toxin for TMJ pain are based on non-randomized studies and one single blind study where the nature of the blinding (patient- or physician-blinded) as well as the time-point for outcome measurement were not described. Botulinum toxin may induce short-term pain relief in cases of temporomandibular disease. The results of this study are also limited by the short follow-up duration. Thus, more RCTs of botulinum toxin in TMJ disorders are needed to support its efficacy.

\section{Low back pain}

Non-randomized study

Ney et al. reported the results of injection of 200-500 units of botulinum toxin A intramuscularly in up to 4-5 trigger points per each side of the back from L2 to S1 in 60 patients with chronic low back pain in an open-label prospective study ${ }^{87}$. The mean age was 47 years, mean disease duration was of 9 years, 18 were women and $62 \%$ had concurrent radicular pain. A positive response was defined by the occurrence of 2 out of the following 3 criteria: a $\geq 50 \%$ improvement in pain VAS scores, an improvement of 2 or more grades in the pain and functional subsets of the Oswestry Low Back Pain Questionnaire, and a $\geq 30 \%$ increase in the number of painfree days from baseline. $58 \%$ of patients responded positively at 2 months and of these $17 \%$ still reported improvement at 4 months of follow-up. Most patients with improvements at 2 months reported 
that the beneficial effects weaned off by 4 months. 18 of the 19 patients that received re-injection reported beneficial response at a 2 month follow up. Two patients reported a mild, flu-like reaction lasting 3-5 days. None of the patients reported any muscle weakness.

\section{$3 \mathrm{RCT}$ in patients with low back pain}

A randomized study by Liu et al. was in Chinese and as a translation was not available, therefore, I could not include a full assessment this review ${ }^{88}$. This 2-month study included 27 patients randomized to acupoint injection of botulinum toxin $\mathrm{A}$ into tender points at the third lumbar transverse process and an acupuncture group treated with acupuncture at the same points as in the acupoint-injection group.

Foster and colleagues compared 200 units of Botulinum toxin A (Allergan) injected intramuscular paravertebrally from L1-5/L2-S1

Table 3. Efficacy outcomes for botulinum toxin in temporomandibular disorder, low back pain, plantar fasciitis and carpal tunnel syndrome in randomized controlled trials.

\begin{tabular}{|c|c|c|c|c|c|c|c|}
\hline Study & $\begin{array}{l}\text { \# Patients } \\
\text { (male/female) }\end{array}$ & $\begin{array}{l}\text { Study type } \\
\text { (duration) }\end{array}$ & Groups & $\begin{array}{l}\text { Mean age } \\
\text { in years } \\
\text { (range) }\end{array}$ & $\begin{array}{l}\text { Mean pain } \\
\text { duration in } \\
\text { months }\end{array}$ & $\begin{array}{l}\text { Primary } \\
\text { outcome }\end{array}$ & Main result - efficacy \\
\hline \multicolumn{8}{|c|}{ Facial pain and temporomandibular disorder } \\
\hline $\begin{array}{l}\text { Von Lindern } \\
\text { et al. }{ }^{86}\end{array}$ & $N=90$ & $\begin{array}{l}\text { Double- } \\
\text { blind } \\
\text { RCT (1-3 } \\
\text { months) }\end{array}$ & $\begin{array}{l}\text { IA-BoNT/A } 35 \\
\text { units }(n=60) \\
\text { Placebo injected } \\
\text { on each side } \\
\text { of masticatory } \\
\text { muscle }(n=30)\end{array}$ & $\begin{array}{l}\text { No } \\
\text { information } \\
\text { provided }\end{array}$ & $\begin{array}{l}\text { Failed } \\
\text { conservative } \\
\text { treatment for } \\
\text { 3-34 months }\end{array}$ & Pain VAS & $\begin{array}{l}\text { Reduction in VAS pain at } \\
1-3 \text { months post-injection } \\
\text { significantly greater in } \\
\text { BoNT versus placebo } \\
(p<0.01 \text { ) } \\
\text { Greater proportion with } \\
\text { a } \geq 2 \text {-point reduction } \\
\text { in VAS pain in BoNT } \\
\text { versus placebo: } ~ 76 \% \\
\text { versus } 10 \% \text { (no statistical } \\
\text { comparisons) }\end{array}$ \\
\hline \multicolumn{8}{|c|}{ Low back pain } \\
\hline $\begin{array}{l}\text { Foster } \\
\text { et al. }\end{array}$ & $\begin{array}{l}N=31 \\
(15 M / 16 F)\end{array}$ & $\begin{array}{l}\text { Double- } \\
\text { blind RCT } \\
\text { (2-months) }\end{array}$ & $\begin{array}{l}200 \text { units IA- } \\
\text { BoNT/A ( } n=15) \\
\text { Placebo injected } \\
\text { into } 5 \text { lumbar } \\
\text { or lumbosacral } \\
\text { sites on more } \\
\text { painful side } \\
(n=16)\end{array}$ & $\begin{array}{l}\text { BoNT: } 47 \\
\text { yrs (20-73) } \\
\text { PL: } 46 \text { yrs } \\
(21-65)\end{array}$ & $\begin{array}{l}\text { BoNT: } 72 \\
\text { (range, } \\
6-120) \\
\text { PL: } 96 \\
\text { (range, } \\
12-360)\end{array}$ & $\begin{array}{l}\text { Pain VAS } \\
\text { Oswestry } \\
\text { Back Pain } \\
\text { Inventory }\end{array}$ & $\begin{array}{l}73 \%(11 / 15) \text { patients in IA- } \\
\text { BoNT/A group had } \geq 50 \% \\
\text { reduction in VAS pain } \\
\text { compared to } 25 \%(4 / 16) \text { in } \\
\text { placebo group at } 3 \text { wks } \\
\text { ( } p=0.012) \\
60 \% \text { in BoNT versus } 13 \% \\
\text { in Placebo had } \geq 50 \% \\
\text { reduction in VAS pain at } \\
\text { 8-wks ( } p=0.009 \text { ) } \\
\text { Improvement in Oswestry } \\
\text { scores were seen in } 67 \% \\
\text { of BoNT and } 19 \% \text { of } \\
\text { placebo-treated patients } \\
\text { at } 8 \text {-wks ( } p=0.011 \text { ) }\end{array}$ \\
\hline $\begin{array}{l}\text { DeAndreas } \\
\text { et al. } .^{96}\end{array}$ & $\begin{array}{l}N=27 \\
(8 \mathrm{M} / 20 \mathrm{~F})\end{array}$ & $\begin{array}{l}\text { Double- } \\
\text { blind RCT } \\
\text { (2-months) }\end{array}$ & $\begin{array}{l}50 \text { units IA- } \\
\text { BoNT/A }(n=27) \\
\text { Saline }(n=13) \\
\text { or Bupivacaine } \\
\text { ( } n=14) \text { on the } \\
\text { opposite side as } \\
\text { BoNT/A }\end{array}$ & $\begin{array}{l}\text { All: } 51 \pm 12 \\
\text { years }\end{array}$ & $\begin{array}{l}\text { No } \\
\text { information } \\
\text { provided }\end{array}$ & $\begin{array}{l}\text { Pain } \\
\text { Hospital } \\
\text { Anxiety and } \\
\text { Depression } \\
\text { scale [HAD-A } \\
\text { and HAD-D], } \\
\text { Lattinen } \\
\text { test, a } \\
\text { questionnaire } \\
\text { of pain } \\
\text { severity and } \\
\text { its impact on } \\
\text { daily living } \\
\text { Oswestry } \\
\text { questionnaire } \\
\text { Spielberger } \\
\text { State-Trait } \\
\text { Anxiety Index }\end{array}$ & $\begin{array}{l}\text { No difference in pain } \\
\text { severity between groups } \\
\text { at any follow-up time } \\
\text { ( } p>0.05 \text { ) } \\
\text { No difference in Lattinen } \\
\text { score }(p=0.011) \text {, } \\
\text { Oswestry score or } \\
\text { HAD-A and HAD-D cores } \\
\text { between groups. }\end{array}$ \\
\hline
\end{tabular}




\begin{tabular}{|c|c|c|c|c|c|c|c|}
\hline Study & $\begin{array}{l}\text { \# Patients } \\
\text { (male/female) }\end{array}$ & $\begin{array}{l}\text { Study type } \\
\text { (duration) }\end{array}$ & Groups & $\begin{array}{l}\text { Mean age } \\
\text { in years } \\
\text { (range) }\end{array}$ & $\begin{array}{l}\text { Mean pain } \\
\text { duration in } \\
\text { months }\end{array}$ & $\begin{array}{l}\text { Primary } \\
\text { outcome }\end{array}$ & Main result - efficacy \\
\hline $\begin{array}{l}\text { Fishman } \\
\text { et al. }{ }^{90}\end{array}$ & $\begin{array}{l}\mathrm{N}=87 ; 67 \\
\text { completed } \\
\text { study (5 } \\
\text { bilateral) } \\
(21 \mathrm{M} / 46 \mathrm{~F})\end{array}$ & $\begin{array}{l}\text { Double- } \\
\text { blind RCT } \\
\text { (12 weeks) }\end{array}$ & $\begin{array}{l}200 \text { units IA- } \\
\text { BoNT/A }(n=21) \\
\text { Triamcinolone }+ \\
\text { lidocaine }(n=31) \\
\text { Placebo }(n=15)\end{array}$ & $\begin{array}{l}\text { All: } 57.4 \pm \\
13.4 \text { years }\end{array}$ & $\begin{array}{l}\text { No } \\
\text { information } \\
\text { provided }\end{array}$ & Pain & $\begin{array}{l}\text { Significant difference in } \\
\text { proportion of patients } \\
\text { with } 50 \% \text { ore more } \\
\text { improvement in pain } \\
\text { severity at each of the last } \\
2 \text { visits between BoNT/A } \\
\text { and placebo }(p=0.001) \\
\text { and triamcinolone/lidocaine } \\
(p=0.04)\end{array}$ \\
\hline \multicolumn{8}{|c|}{ Plantar fasciitis } \\
\hline $\begin{array}{l}\text { Babcock } \\
\text { et al. } .^{92}\end{array}$ & $\begin{array}{l}N=27 \\
(43 \text { feet) } \\
(9 M / 18 F)\end{array}$ & $\begin{array}{l}\text { Double- } \\
\text { blind RCT } \\
\text { (2-months) }\end{array}$ & $\begin{array}{l}70 \text { Units BoNT A } \\
(n=22) \\
\text { Placebo ( } 40 \text { units } \\
\text { on medial aspect } \\
\text { of the heel and } \\
30 \text { units in the } \\
\text { foot arch }(n=21)\end{array}$ & $\begin{array}{l}\text { All: Median } \\
\text { age, } 44 \\
\text { (range, } \\
\text { 21-65) }\end{array}$ & $\begin{array}{l}\text { No } \\
\text { information } \\
\text { provided }\end{array}$ & $\begin{array}{l}\text { Pain VAS } \\
(0-10 \mathrm{~cm}) \\
\text { Pressure } \\
\text { algometry } \\
\text { Maryland } \\
\text { Foot Score } \\
(0-100) \\
\text { Pain } \\
\text { relief VAS } \\
(0-10 \mathrm{~cm})\end{array}$ & $\begin{array}{l}\text { At } 3 \text { weeks, improvements } \\
\text { were significantly } \\
\text { higher for BoNT versus } \\
\text { placebo: pain VAS }-2.7 \\
\text { ( } 39 \% \text { decrease) vs. } 4.7 \\
\text { ( } p<0.004) \text {; Maryland } \\
\text { Foot score }-72(34 \%) \\
\text { vs. } 49 \text { ( } p=0.001) ; \\
\text { pressure algometry - } 2.7 \\
\text { ( } 40 \% \text { increase) vs. } 1.8 \\
\text { ( } p=0.003) ; \text { and pain } \\
\text { improvement scale, } 4.8 \text { vs. } \\
0.6 \text { ( } p<0.005 \text { ) } \\
\text { At } 8 \text { weeks, improvements } \\
\text { were significantly } \\
\text { higher for BoNT versus } \\
\text { placebo: pain VAS - } 1.6 \\
(56 \% \text { decrease) vs. } 4.4 \\
\text { ( } p<0.005) ; \text { Maryland } \\
\text { Foot score - } 81 \text { ( } 47 \%) \\
\text { vs. } 54 \text { ( } p=0.001) ; \\
\text { pressure algometry - } 2.8 \\
(56 \% \text { increase) vs. } 1.8 \\
(p=0.003) ; \text { and pain } \\
\text { improvement scale, } 5.0 \text { vs. } \\
1.2 \text { ( } p<0.005 \text { ) }\end{array}$ \\
\hline \multicolumn{8}{|c|}{ Hand pain and carpal tunnel syndrome } \\
\hline $\begin{array}{l}\text { Breuer } \\
\text { et al. } .^{93}\end{array}$ & $N=20$ & $\begin{array}{l}\mathrm{RCT}, \\
\text { Double-blind, } \\
\text { 3-months }\end{array}$ & $\begin{array}{l}2,500 \text { units } \\
\text { BoNT-B ( } n=11) \\
\text { Placebo injected } \\
\text { into } 3 \text { hypothenar } \\
\text { muscles in } \\
\text { carpal tunnel } \\
(n=9)\end{array}$ & $\begin{array}{l}\text { No } \\
\text { information } \\
\text { provided }\end{array}$ & $\begin{array}{l}\text { No } \\
\text { information } \\
\text { provided }\end{array}$ & $\begin{array}{l}\text { NRS Pain } \\
\text { WHYMPI }\end{array}$ & $\begin{array}{l}\text { Pain scores, pain related } \\
\text { sleep disturbances and } \\
\text { WHYMPI scores improved } \\
\text { in both groups at follow- } \\
\text { up, but didn't significantly } \\
\text { differ between groups. } \\
\text { At } 6 \text { weeks, } 8 / 10 \text { ( } 80 \%) \\
\text { BoNT patients versus } \\
6 / 9(67 \%) \text { placebo } \\
\text { patients had a clinically } \\
\text { meaningful reduction of } \\
\text { pain VAS scores (30\% } \\
\text { or } 2 \text {-point reduction). At } \\
13 \text { weeks } 2 / 7 \text { (29\%) in } \\
\text { the BoNT group versus } \\
4 / 9 \text { (44\%) in the placebo } \\
\text { group experienced a } \\
30 \% / 2-\text { point reduction in } \\
\text { VAS pain scores. }\end{array}$ \\
\hline
\end{tabular}

RCT, randomized controlled trial; NRS, Numeric Rating Scale; VAS, Visual analog scale; WHYMPI, West Haven-Yale Multidimensional Pain Inventory.

$(\mathrm{n}=15)$ to placebo $(\mathrm{n}=16)$ in 31 patients with chronic back pain of $\geq 6$ month duration ${ }^{89}$ (Table 3). 40 units/site were injected at five lumbar paravertebral levels on the side of maximum discomfort. The mean age was 46 years, 16 were women and the mean pain duration was 6 years (with a range of $0.5-30$ years). The number of individuals experiencing greater than $50 \%$ reduction in VAS pain scores from baseline was significantly higher in the botulinum toxin group compared with placebo: $73 \%$ vs. $25 \%$ at 3 weeks $(p=0.012)$, 
and $60 \%$ vs. $13 \%$ at 8 -weeks $(p=0.009)$. The Oswestry Low Back Pain Questionnaire score improved significantly more patients in patients receiving Botox (67\%) compared with those receiving placebo $(19 \%, p=0.011)$. No patient reported worsening of pain or function after the BoNT injection, but two patients reported worsening of pain after placebo injections.

DeAndreas et al. compared the efficacy of botulinum toxin A to control (saline or bupivacaine $0.25 \%$ ) in relieving myofascial pain in patients experiencing mechanical low back pain due to bilateral myofascial pain syndrome involving the iliopsoas and/or the quadratus lumborum muscles ${ }^{90} .27$ patients who were enrolled in the study received a bilateral, fluoroscopically guided injection in the affected muscle(s) to randomly deliver botulinum toxin A to one side of the low back and a control drug in the opposite side. Botulinum toxin A injection did not significantly reduce pain more than saline or bupivacaine control in the contralateral side. No significant differences between groups were noted in improvement of patients' daily life activities or psychologic status.

A double-blinded randomized study by Fishman et al. evaluated the efficacy of botulinum toxin A injections used in conjunction with physical therapy for the treatment of back pain due to piriformis syndrome in a 12 -week study ${ }^{90} .67$ patients received 72 injections ( 5 bilateral) and were assigned to one of the three groups, botulinum toxin A, triamcinolone + lidocaine or saline placebo. All patients received therapy. Patients injected with botulinum toxin A experienced more pain relief than patients receiving lidocaine with corticosteroid $(\mathrm{p}=0.04)$ or saline placebo $(\mathrm{p}=0.001)$.

\section{Summary and study limitations: low back pain}

In summary, intramuscular injections of botulinum toxin in patients with chronic back pain seemed to provide short-term benefits of pain reduction. This is based on one non-randomized study and two RCTs in patients with chronic low back pain. Both RCTs had a small sample size and included patients with chronic symptoms. Pain improvement was noted in both RCTs and function, measured in one study, also improved. The effects were not assessed at longterm follow-up, i.e., at 6-months or longer. In addition, in one study all groups received physical therapy, and therefore the effects in the intervention arm may be attributable to an interaction between therapy and botulinum toxin. More evidence is needed to examine the utility of botulinum toxin in the treatment of back pain.

\section{Plantar fasciitis}

\section{Non-randomized study}

Placzek et al. reported a case series of 9 patients with chronic plantar fasciitis, who were injected with 200 units of botulinum toxin A (Dysport) in the plantar fascia ${ }^{91}$. Patients were followed up to one year after the injection. Statistically significant pain relief began two weeks after the injection (from 4.2 to 1.9 on a $0-10$ VAS pain scale, $\mathrm{p}=0.012$ ) and persisted for the 52 weeks of follow up (from 4.2 to $0.4, p=0.043$ ). Muscle weakness or systemic effects were not seen.

One RCT in patients with heel pain and plantar fasciitis Babcock and colleagues compared 70 units of Botulinum toxin A injected into the plantar fascia at two sites per foot to a placebo in
27 patients (43 feet in total) who had experienced chronic refractory plantar fasciitis for 6 months or more, and who had failed to respond to conventional therapies except surgery or extracorporeal shock therapy $^{92}$ (Table 3 ). In this study, 22 feet were randomized to BoNT/A and 21 to placebo. The median age was 44 years and 18 patients (12 with bilateral and six with unilateral plantar fascia) were women. Of the sixteen bilateral patients (male and female), 12 improved on all measures in the BoNT/A-treated foot and only one improved in the placebo-treated foot. Both pain and pain relief were measured on separate $0-10 \mathrm{~cm}$ VAS scales. Compared to the placebo group, the Botulinum toxin group had significantly improved VAS pain relief scores $(4.75 \mathrm{~cm}$ vs. $0.6 \mathrm{~cm}$ at 3 weeks and $4.95 \mathrm{~cm}$ vs. $1.2 \mathrm{~cm}$ at 8 weeks, $\mathrm{p}<0.005$ for both), significantly lower VAS pain scores $(2.7 \mathrm{~cm}$ vs. $4.7 \mathrm{~cm}$ at 3 weeks and $1.6 \mathrm{~cm}$ vs. $4.4 \mathrm{~cm}$ at 8 weeks, $\mathrm{p}<0.005$ for both), significantly better foot function as assessed by the Maryland Foot Score (100-point scale) (72 vs. 49 at 3 weeks and 81 vs. 54 at 8 weeks, $p<0.001$ for both) and less muscle tenderness at plantar fascia insertion as assessed by a pressure algometry response (2.7 vs. 1.8 at 3 weeks and 2.8 vs. 1.8 at 8 weeks, $\mathrm{p}<0.003$ for both). No complications were reported.

\section{Summary and study limitations: plantar fasciitis}

In summary, the evidence is based on one non-randomized study and one RCT. Pain and function both improved short-term in botulinum toxin compared to placebo at 3- and 8-week follow-up in RCT and pain improved up to 1-year follow-up in the non-randomized study. While the data seems promising, more RCTs are needed and evidence of efficacy at longer-term is needed to assess whether botulinum toxin can provide a longer-term relief in patients with plantar fasciitis.

\section{Hand pain and carpal tunnel syndrome}

Breuer and colleagues randomized 20 patients with carpal tunnel syndrome with associated hand pain to receive electromyographically guided placebo or botulinum toxin B injections in three hypothenar muscles anatomically attached to the carpal tunnel ${ }^{93}$ (Table 3). The dose used in 18 of the 20 patients due to modified protocol was 2,500 units, since the first two patients reported weakness and stiffness of the fourth and fifth fingers with higher doses of 5000 and 7500 units. During the 13-week trial, significant decreases in pain outcomes and improvements in function were noted in both placebo and the BoNT/A groups compared to the baseline, but there were no significant differences between the two groups. The unblinding of the first two patients and variation in the BoNT/A dose during the trial make interpretation of findings from this study difficult.

\section{Anterior knee pain}

One non-randomized study provides evidence for the use of botulinum toxin in cases of anterior knee pain. Singer et al. injected 300 to 500 units of botulinum toxin A (Dysport) into the vastus lateralis muscle in 8 women with chronic anterior knee pain of more than 6 months duration who had failed to respond to conservative management, e.g. patello-femoral bracing or taping ${ }^{94}$ (Table 3). The injection was followed by a 12-week home exercise program to strengthen the vastus medialis. The mean age was 29 years and mean symptom duration was 5 years (range, 1-19 years). Patients reported a decrease in knee pain (individual changes were shown in 
the article, not means), an increase in function with an improvement in the mean force production in the affected limb from $22.7 \mathrm{~kg}$ to $24.3 \mathrm{~kg}$ ) and an improvement in the mean time taken to ascend and descend a flight of 11 stairs from 12 to 10 seconds. These improvements were maintained at a 24 -week follow up.

\section{Hip pain}

One non-randomized study provides evidence for the use of botulinum toxin in hip pain. A total of 400 units of Botulinum toxin type A (Dysport) were injected into the adductor longus and the adductor magnus muscles in 39 patients with hip osteoarthritis ${ }^{95}$. The mean age was 68 years (age range $41-82$ years). The Harris Hip Score, a commonly used measure of hip function, increased significantly after 2, 4 and 12 weeks after the BoNT/A injection $(\mathrm{p}<0.0001)$. There was a significant decrease in pain 2,4 and 12 weeks after the BoNT/A injection $(\mathrm{p}<0.001)$.

\section{Limitations of this review}

This was a focused review of randomized and non-randomized studies, not a systematic review or a meta-analysis. Therefore findings must be interpreted with caution. In particular, the summary section for various musculoskeletal pain disorders highlights the limitation of studies included. In particular, evidence for the efficacy of botulinum toxin in anterior knee pain and hip pain was based on nonrandomized study data only (one study for each), and is subject to bias. Also, the evidence presented here includes both intramuscular and intra-articular injections for a variety of musculoskeletal disorders. Even though presented together, their effects may differ. The intramuscular injections may have complex effects, including the analgesic effects, effects from blocking acetylcholine release from motor nerve endings, and the elimination of muscle myofascial trigger points ${ }^{96}$. On the other hand, intra-articular injections may work primarily by their effect on the analgesic pathways ${ }^{97}$.

\section{Summary and conclusions}

In this review, I have summarized studies of the use of botulinum toxin for musculoskeletal pain. Most studies used either an intra-articular or intramuscular route of administration in patients with refractory pain, who had not responded to multiple other treatment interventions. Pre-clinical laboratory evidence supports an independent anti-nociceptive mechanism of action of botulinum toxin. While there are several osteoarticular conditions for which botulinum toxin has been studied in an RCT compared to placebo, for several conditions such as low back pain, plantar fasciitis, temporomandibular disorder and carpal tunnel syndrome, the evidence is based on non-randomized data and only a single RCT. For other conditions, such as osteoarthritis of the knee/shoulder and tennis elbow data in support of its use from several RCTs and non-randomized studies was available. Most RCTs included in this review had several limitations. Most studies were single center, had a small sample size, short follow-up and in some cases, non-standardized injection techniques. The evidence for an anti-nociceptive action of botulinum toxin in osteoarticular pain is growing. Side effects seem to be mild, and in cases of muscle weakness, reversible; however, data from larger samples needs to be generated. Evidence from larger multicenter studies of longer duration that test various doses, regimens and routes of administration of botulinum toxin are needed to better define its role in management of osteoarticular pain.

\section{Competing interests}

There are no financial competing interests related directly to this study. JAS has received research and travel grants from Takeda, Savient, and Allergan; and consultant fees from URL pharmaceuticals, Savient, Takeda, Regeneron, Ardea, Allergan and Novartis. The views expressed in this article are those of the author and do not necessarily reflect the position or policy of the Department of Veterans Affairs or the United States government.

\section{Grant information}

No funding was obtained for this work. JAS is also supported by grants from the Agency for Health Quality and Research Center for Education and Research on Therapeutics (CERTs), National Institute of Aging and National Cancer Institute and the resources and use of facilities at the Birmingham VA Medical Center, Alabama, USA.

The funders had no role in study design, data collection and analysis, decision to publish, or preparation of the manuscript.
1. Institute of Medicine: Relieving Pain in America: A Blueprint for Transforming Prevention, Care, Education, and Research. Washington, D.C.: The National Academies Press; 2011.

PubMed Abstract

2. Breivik $\mathrm{H}$, Collett $B$, Ventafridda $V$, et al.: Survey of chronic pain in Europe: prevalence, impact on daily life, and treatment. Eur J Pain. 2006; 10(4): 287-333. PubMed Abstract | Publisher Full Text

3. CDC: Prevalence of doctor-diagnosed arthritis and arthritis-attributable activity limitation - United States, 2007-2009. MMWR Morb Mortal Wkly Rep. 2010; 59(39): 1261-5

PubMed Abstract

4. CDC: Prevalence and most common causes of disability among adults United States, 2005. MMWR Morb Mortal Wkly Rep. 2009; 58(16): 421-6. PubMed Abstract

5. Stoddard S, Jans L, Ripple JM, et al:: Chartbook on work and disability in the United States, 1998. Washington, DC: US National Institute on Disability and Rehabilitation Research; 1998. Reference Source
6. Helmick CG, Felson DT, Lawrence RC, et al.: Estimates of the prevalence of arthritis and other rheumatic conditions in the United States. Part I. Arthritis Rheum. 2008; 58(1): 15-25.

PubMed Abstract | Publisher Full Text

7. United States Bone and Joint Decade: The Burden of Musculoskeletal Diseases in the United States. Rosemont, IL; American Academy of Orthopaedic Surgeons [Data Source: 2004 National Ambulatory Medical Care Survey (NAMCS) and the 1997 National Hospital Ambulatory Medical Care Survey (NHAMCS)]. Rosemont, IL: USBJD; 2008 [12/20/2012]

Reference Source

8. CDC: National and state medical expenditures and lost earnings attributable to arthritis and other rheumatic conditions-United States, 2003. MMWR Morb Mortal Wkly Rep. 2007; 56(1): 4-7. PubMed Abstract | Free Full Text

9. Hart LG, Deyo RA, Cherkin DC: Physician office visits for low back pain. Frequency, clinical evaluation, and treatment patterns from a U.S. national survey. Spine (Phila Pa 1976). 1995; 20(1): 11-19.

PubMed Abstract | Publisher Full Text 
10. Deyo RA, Mirza SK, Martin BI: Back pain prevalence and visit rates: estimates from U.S. national surveys, 2002. Spine (Phila Pa 1976). 2006; 31(23): 2724-7. PubMed Abstract | Publisher Full Text

11. Lawrence RC, Helmick CG, Arnett FC, et al.: Estimates of the prevalence of arthritis and selected musculoskeletal disorders in the United States. Arthritis Rheum. 1998; 41(5): 778-99.

PubMed Abstract | Publisher Full Text

12. Frymoyer JW, Cats-Baril WL: An overview of the incidences and costs of low back pain. Orthop Clin North Am. 1991; 22(2): 263-71. PubMed Abstract

13. Katz JA: Getting the lowdown on back pain. Nursing. 2001; 31(12): 24 PubMed Abstract

14. Schaible HG: Why does an inflammation in the joint hurt? Br J Rheumatol. 1996; 35(5): 405-6.

PubMed Abstract | Publisher Full Text

15. Schaible HG: Peripheral and central mechanisms of pain generation. Handb Exp Pharmacol. 2007; (177): 3-28. PubMed Abstract | Publisher Full Text

16. Schaible HG, Ebersberger A, Von Banchet GS: Mechanisms of pain in arthritis. Ann NY Acad Sci. 2002; 966: 343-54.

PubMed Abstract | Publisher Full Text

17. Schaible HG, Schmelz M, Tegeder I: Pathophysiology and treatment of pain in joint disease. Adv Drug Deliv Rev. 2006; 58(2): 323-42.

PubMed Abstract | Publisher Full Text

18. Schaible HG, Richter F, Ebersberger A, et al.: Joint pain. Exp Brain Res. 2009; 196(1): 153-62.

PubMed Abstract | Publisher Full Text

19. Neugebauer V, Lücke T, Schaible HG: N-methyl-D-aspartate (NMDA) and nonNMDA receptor antagonists block the hyperexcitability of dorsal horn neuron during development of acute arthritis in rat's knee joint. J Neurophysiol. 1993; 70(4): 1365-77.

PubMed Abstract

20. Schaible HG, Schmidt RF, Willis WD: Enhancement of the responses of ascending tract cells in the cat spinal cord by acute inflammation of the knee joint. Exp Brain Res. 1987; 66(3): 489-99.

PubMed Abstract | Publisher Full Text

21. Schaible HG, Del Rosso A, Matucci-Cerinic M: Neurogenic aspects of inflammation. Rheum Dis Clin North Am. 2005; 31(1): 77-101, ix. PubMed Abstract | Publisher Full Text

22. Watkins LR, Maier SF: Glia: a novel drug discovery target for clinical pain. Nat Rev Drug Discov. 2003; 2(12): 973-85. PubMed Abstract | Publisher Full Text

23. Watkins LR, Milligan ED, Maier SF: Glial proinflammatory cytokines mediate exaggerated pain states: implications for clinical pain. Adv Exp Med Biol. 2003 521: 1-21

PubMed Abstract

24. Watkins LR, Maier SF: Beyond neurons: evidence that immune and glial cells contribute to pathological pain states. Physiol Rev. 2002; 82(4): 981-1011. PubMed Abstract | Publisher Full Text

25. Woolf CJ, Allchorne A, Safieh-Garabedian B, et al.: Cytokines, nerve growth factor and inflammatory hyperalgesia: the contribution of tumour necrosis factor alpha. Br J Pharmacol. 1997; 121(3): 417-24.

PubMed Abstract | Publisher Full Text | Free Full Text

26. Woolf CJ, Safieh-Garabedian B, Ma QP, et al:: Nerve growth factor contributes to the generation of inflammatory sensory hypersensitivity. Neuroscience. 1994; 62(2): 327-31.

PubMed Abstract | Publisher Full Text

27. Woolf $\mathbf{C}$, Wiesenfeld-Hallin Z: Substance $\mathbf{P}$ and calcitonin gene-related peptide synergistically modulate the gain of the nociceptive flexor withdrawal reflex in the rat. Neurosci Lett. 1986; 66(2): 226-30.

PubMed Abstract | Publisher Full Text

28. Jones SL: Descending noradrenergic influences on pain. Prog Brain Res. 1991; 88: 381-94.

PubMed Abstract | Publisher Full Text

29. Willis WD, Westlund KN: Neuroanatomy of the pain system and of the pathways that modulate pain. J Clin Neurophysiol. 1997; 14(1): 2-31. PubMed Abstract | Publisher Full Text

30. Woolf CJ: American College of Physicians; American Physiological Society: Pain: moving from symptom control toward mechanism-specific pharmacologic management. Ann Intern Med. 2004; 140(6): 441-51. PubMed Abstract

31. Woolf CJ, Costigan M: Transcriptional and posttranslational plasticity and the generation of inflammatory pain. Proc Natl Acad Sci U S A. 1999; 96(14): $7723-30$.

PubMed Abstract | Publisher Full Text | Free Full Text

32. Woolf CJ, Decosterd I: Implications of recent advances in the understanding of pain pathophysiology for the assessment of pain in patients. Pain. 1999; 82(Suppl 6): S141-7.

PubMed Abstract | Publisher Full Text

33. Woolf CJ, Mannion RJ: Neuropathic pain: aetiology, symptoms, mechanisms, and management. Lancet. 1999; 353(9168): 1959-64.

PubMed Abstract | Publisher Full Text
34. Ge Z, Hu Y, Heng BC, et al.: Osteoarthritis and therapy. Arthritis Rheum. 2006; 55(3): 493-500

PubMed Abstract | Publisher Full Text

35. Zhang W, Moskowitz RW, Nuki G, et al:: OARSI recommendations for the management of hip and knee osteoarthritis, Part II: OARSI evidence-based, expert consensus guidelines. Osteoarthritis Cartilage. 2008; 16(2): 137-62. PubMed Abstract | Publisher Full Text

36. Zhang W, Moskowitz RW, Nuki G, et al:: OARSI recommendations for the management of hip and knee osteoarthritis, part I: critical appraisal of existing treatment guidelines and systematic review of current research evidence. Osteoarthritis Cartilage. 2007; 15(9): 981-1000.

PubMed Abstract | Publisher Full Text

37. Bellamy N, Campbell J, Robinson V, et al.: Intraarticular corticosteroid for treatment of osteoarthritis of the knee. Cochrane Database Syst Rev. 2006; (2) CD005328

PubMed Abstract | Publisher Full Text

38. Bellamy N, Campbell J, Robinson V, et al:: Viscosupplementation for the treatment of osteoarthritis of the knee. Cochrane Database Syst Rev. 2006; (2) CD005321

PubMed Abstract | Publisher Full Text

39. van der Windt DA, Bouter LM: Physiotherapy or corticosteroid injection for shoulder pain? Ann Rheum Dis. 2003; 62(5): 385-7.

PubMed Abstract | Publisher Full Text | Free Full Text

40. Green S, Buchbinder R, Glazier R, et al.: Interventions for shoulder pain Cochrane Database Syst Rev. 2000; (2): CD001156.

PubMed Abstract | Publisher Full Text

41. Rains C, Bryson HM: Topical capsaicin. A review of its pharmacological properties and therapeutic potential in post-herpetic neuralgia, diabetic neuropathy and osteoarthritis. Drugs Aging. 1995; 7(4): 317-28. PubMed Abstract | Publisher Full Text

42. Jamtvedt G, Dahm KT, Christie A, et al.: Physical therapy interventions for patients with osteoarthritis of the knee: an overview of systematic reviews. Phys Ther. 2008; 88(1): 123-36.

PubMed Abstract | Publisher Full Text

43. Birklein F, Schmelz M: Neuropeptides, neurogenic inflammation and complex regional pain syndrome (CRPS). Neurosci Lett. 2008; 437(3): 199-202. PubMed Abstract | Publisher Full Text

44. Cui M, Khanijou S, Rubino J, et al.: Subcutaneous administration of botulinum toxin A reduces formalin-induced pain. Pain. 2004; 107(1-2): 125-33. PubMed Abstract | Publisher Full Text

45. Lucioni A, Bales GT, Lotan TL, et al:: Botulinum toxin type A inhibits sensory neuropeptide release in rat bladder models of acute injury and chronic inflammation. BJU Int. 2008; 101(3): 366-70.

PubMed Abstract | Publisher Full Text

46. Purkiss J, Welch M, Doward S, et al:: Capsaicin-stimulated release of substance $P$ from cultured dorsal root ganglion neurons: involvement of two distinct mechanisms. Biochem Pharmacol. 2000; 59(11): 1403-6.

PubMed Abstract | Publisher Full Text

47. Rapp DE, Turk KW, Bales GT, et al.: Botulinum toxin type a inhibits calcitonin gene-related peptide release from isolated rat bladder. $J$ Urol. 2006; 175(3 Pt 1): 1138-42.

PubMed Abstract | Publisher Full Text

48. Durham PL, Cady R, Cady R: Regulation of calcitonin gene-related peptide secretion from trigeminal nerve cells by botulinum toxin type $A$ : implications for migraine therapy. Headache. 2004; 44(1): 35-42; discussion 42-3. PubMed Abstract | Publisher Full Text

49. Meng J, Wang J, Lawrence G, et al:: Synaptobrevin I mediates exocytosis of CGRP from sensory neurons and inhibition by botulinum toxins reflects their anti-nociceptive potential. J Cell Sci. 2007; 120(Pt 16): 2864-74. PubMed Abstract | Publisher Full Text

50. Purkiss J, Welch M, Doward S, et al:: Capsicin stimulated release of substance $P$ from cultured dorsal root ganglion neurons: involvement of two distinct mechanisms. Biochem Pharmacol. 2000; 59(11): 1403-6. PubMed Abstract | Publisher Full Text

51. Larsson J, Ekblom A, Henriksson $\mathrm{K}$, et al:: Concentration of substance $\mathbf{P}$, neurokinin $\mathrm{A}$, calcitonin gene-related peptide, neuropeptide $\mathrm{Y}$ and vasoactive intestinal polypeptide in synovial fluid from knee joints in patients suffering from rheumatoid arthritis. Scand J Rheumatol. 1991; 20(5): 326-35. PubMed Abstract | Publisher Full Text

52. Kar S, Gibson SJ, Rees RG, et al.: Increased calcitonin gene-related peptide (CGRP), substance P, and enkephalin immunoreactivities in dorsal spinal cord and loss of CGRP-immunoreactive motoneurons in arthritic rats depend on intact peripheral nerve supply. $J$ Mol Neurosci. 1991; 3(1): 7-18. PubMed Abstract | Publisher Full Text

53. Devillier P, Weill B, Renoux M, et al.: Elevated levels of tachykinin-like immunoreactivity in joint fluids from patients with rheumatic inflammatory diseases. N Engl J Med. 1986; 314(20): 1323. PubMed Abstract | Publisher Full Text

54. Ahmed M, Bjurholm A, Schultzberg M, et al:: Increased levels of substance $\mathbf{P}$ and calcitonin gene-related peptide in rat adjuvant arthritis. A combined immunohistochemical and radioimmunoassay analysis. Arthritis Rheum. 1995 38(5): 699-709.

PubMed Abstract | Publisher Full Text 
55. Krämer $\mathrm{HH}$, Angerer $\mathrm{C}$, Erbguth $\mathrm{F}$, et al:: Botulinum Toxin A reduces neurogenic flare but has almost no effect on pain and hyperalgesia in human skin. $J$ Neurol. 2003; 250(2): 188-93.

PubMed Abstract | Publisher Full Text

56. Yuan RY, Sheu JJ, Yu JM, et al.: Botulinum toxin for diabetic neuropathic pain: a randomized double-blind crossover trial. Neurology. 2009; 72(17): 1473-8. PubMed Abstract | Publisher Full Text

57. Ranoux D, Attal N, Morain F, et al.: Botulinum toxin type $\mathbf{A}$ induces direct analgesic effects in chronic neuropathic pain. Ann Neurol. 2008; 64(3): 274-83.

PubMed Abstract | Publisher Full Text

58. Sycha T, Samal D, Chizh B, et al:: A lack of antinociceptive or antiinflammatory effect of botulinum toxin A in an inflammatory human pain model. Anesth Analg. 2006; 102(2): 509-16.

PubMed Abstract | Publisher Full Text

59. Blersch W, Schulte-Mattler WJ, Przywara S, et al: Botulinum toxin A and the cutaneous nociception in humans: a prospective, double-blind, placebocontrolled, randomized study. J Neurol Sci. 2002; 205(1): 59-63. PubMed Abstract | Publisher Full Text

60. Voller B, Sycha T, Gustorff B, et al:: A randomized, double-blind, placebo controlled study on analgesic effects of botulinum toxin A. Neurology. 2003; 61(7): 940-4.

PubMed Abstract | Publisher Full Text

61. Singh JA: Botulinum toxin therapy for osteoarticular pain: an evidence-based review. Ther Adv Musculoskelet Dis. 2010; 2(2): 105-18. PubMed Abstract | Publisher Full Text | Free Full Text

62. Ho KY, Tan $\mathrm{KH}$ : Botulinum toxin $\mathbf{A}$ for myofascial trigger point injection: a qualitative systematic review. Eur J Pain. 2007; 11(5): 519-27. PubMed Abstract | Publisher Full Text

63. Cuevas-Trisán RL, Cruz-Jimenez M: The use of botulinum toxin in physical medicine and rehabilitation. Bol Asoc Med P R. 2006; 98(1): 42-55. PubMed Abstract

64. Hameed F, Ihm J: Injectable medications for osteoarthritis. PM R. 2012; 4(5 Suppl): S75-S81.

PubMed Abstract | Publisher Full Text

65. Cheng OT, Souzdalnitski D, Vrooman B, et al.: Evidence-based knee injections for the management of arthritis. Pain Med. 2012; 13(6): 740-753. PubMed Abstract | Publisher Full Text | Free Full Text

66. Sim WS: Application of botulinum toxin in pain management. Korean J Pain. 2011; 24(1): 1-6.

PubMed Abstract | Publisher Full Text | Free Full Text

67. Mahowald ML, Singh JA, Dykstra D: Long term effects of intra-articular botulinum toxin A for refractory joint pain. Neurotox Res. 2006; 9(2-3): 179-88. PubMed Abstract | Publisher Full Text

68. Singh JA, Mahowald ML, Kushnaryov A, et al:: Repeat injections of intra-articula botulinum toxin a for the treatment of chronic arthritis joint pain. $J$ Clin Rheumatol. 2009; 15(1): 35-8.

PubMed Abstract | Publisher Full Text

69. Dykstra D, Stuckey M, Schimpff S, et al:: The effects of intra-articular botulinum toxin on sacroiliac, cervical/lumbar facet and sterno-calvicular joint pain and $\mathrm{C}-2$ root and lumbar disc pain: a case series of 11 patients. The Pain Clinic. 2007; 19(1): 27-32.

Publisher Full Text

70. Singh JA, Mahowald ML, Noorbaloochi S: Intra-articular botulinum toxin A for refractory shoulder pain: a randomized, double-blinded, placebo-controlled trial. Transl Res. 2009; 153(5): 205-16.

PubMed Abstract | Publisher Full Text

71. Farrar JT, Portenoy RK, Berlin JA, et al.: Defining the clinically important difference in pain outcome measures. Pain. 2000; 88(3): 287-94. PubMed Abstract | Publisher Full Text

72. Farrar JT, Young JP Jr, LaMoreaux L, et al:: Clinical importance of changes in chronic pain intensity measured on an 11-point numerical pain rating scale. Pain. 2001; 94(2): 149-58.

PubMed Abstract | Publisher Full Text

73. Boon AJ, Smith J, Dahm DL, et al:: Efficacy of intra-articular botulinum toxin type A in painful knee osteoarthritis: a pilot study. PM R. 2010; 2(4): 268-76. PubMed Abstract | Publisher Full Text

74. Mahowald ML, Krug HE, Singh JA, et al:: Intra-articular Botulinum Toxin Type A: a new approach to treat arthritis joint pain. Toxicon. 2009; 54(5): 658-67. PubMed Abstract | Publisher Full Text

75. Singh JA, Mahowald ML: Intra-articular botulinum toxin A as an adjunctive therapy for refractory joint pain in patients with rheumatoid arthritis receiving biologics: a report of two cases. Joint Bone Spine. 2009; 76(2): 190-4. PubMed Abstract | Publisher Full Text

76. Morré HH, Keizer SB, van Os JJ: Treatment of chronic tennis elbow with botulinum toxin. Lancet. 1997; 349(9067): 1746 PubMed Abstract | Publisher Full Text

77. Hayton MJ, Santini AJ, Hughes PJ, et al.: Botulinum toxin injection in the treatment of tennis elbow. A double-blind, randomized, controlled, pilot study. $J$ Bone Joint Surg Am. 2005; 87(3): 503-7.

PubMed Abstract | Publisher Full Text
78. Singh JA, Mahowald ML, Noorbaloochi S: Intraarticular botulinum toxin A for refractory painful total knee arthroplasty: a randomized controlled trial. J Rheumatol. 2010; 37(11): 2377-86

PubMed Abstract | Publisher Full Text | Free Full Text

79. Wong SM, Hui AC, Tong PY, et al.: Treatment of lateral epicondylitis with botulinum toxin: a randomized, double-blind, placebo-controlled trial. Ann Intern Med. 2005; 143(11): 793-7.

PublMed Abstract | Publisher Full Text

80. Keizer SB, Rutten HP, Pilot $P$, et al:: Botulinum toxin injection versus surgical treatment for tennis elbow: a randomized pilot study. Clin Orthop Relat Res. 2002; (401): 125-31.

PubMed Abstract | Publisher Full Text

81. Lin YC, Tu YK, Chen SS, et al:: Comparison between botulinum toxin and corticosteroid injection in the treatment of acute and subacute tennis elbow: a prospective, randomized, double-blind, active drug-controlled pilot study. Am J Phys Med Rehabil. 2010; 89(8): 653-9. PubMed Abstract | Publisher Full Text

82. Placzek R, Drescher W, Deuretzbacher G, et al:: Treatment of chronic radia epicondylitis with botulinum toxin A. A double-blind, placebo-controlled, randomized multicenter study. J Bone Joint Surg Am. 2007; 89(2): 255-60. PubMed Abstract | Publisher Full Text

83. von Lindern JJ: Type A botulinum toxin in the treatment of chronic facial pain associated with temporo-mandibular dysfunction. Acta Neurol Belg. 2001; 101(1): 39-41.

PubMed Abstract

84. Freund B, Schwartz M, Symington JM: Botulinum toxin: new treatment for temporomandibular disorders. Br J Oral Maxillofac Surg. 2000; 38(5): 466-71. PubMed Abstract | Publisher Full Text

85. Freund B, Schwartz M, Symington JM: The use of botulinum toxin for the treatment of temporomandibular disorders: preliminary findings. J Oral Maxillofac Surg. 1999; 57(8): 916-20; discussion 920-1.

PubMed Abstract | Publisher Full Text

86. von Lindern JJ, Niederhagen B, Bergé S, et al:: Type A botulinum toxin in the treatment of chronic facial pain associated with masticatory hyperactivity. J Oral Maxillofac Surg. 2003; 61(7): 774-8.

PubMed Abstract | Publisher Full Text

87. Ney JP, Difazio M, Sichani A, et al:: Treatment of chronic low back pain with successive injections of botulinum toxin a over 6 months: a prospective trial of 60 patients. Clin J Pain. 2006; 22(4): 363-9.

PubMed Abstract | Publisher Full Text

88. Liu Z: [Botulinum toxin A (BTX-A) point injection for treatment of the third lumbar transverse process syndrome]. Zhongguo Zhen Jiu. 2008; 28(5): 337-9. PubMed Abstract

89. Foster L, Clapp L, Erickson M, et al.: Botulinum toxin A and chronic low back pain: a randomized, double-blind study. Neurology. 2001; 56(10): 1290-3. PubMed Abstract | Publisher Full Text

90. De Andres J, Adsuara VM, Palmisani S, et al:: A double-blind, controlled, randomized trial to evaluate the efficacy of botulinum toxin for the treatment of lumbar myofascial pain in humans. Reg Anesth Pain Med. 2010; 35(3): 255-60. PubMed Abstract | Publisher Full Text

91. Fishman LM, Anderson C, Rosner B: BOTOX and physical therapy in the treatment of piriformis syndrome. Am J Phys Med Rehabil. 2002; 81(12): 936-42. PubMed Abstract | Publisher Full Text

92. Placzek R, Deuretzbacher G, Buttgereit F, et al:: Treatment of chronic plantar fasciitis with botulinum toxin $A$ : an open case series with a 1 year follow up. Ann Rheum Dis. 2005; 64(11): 1659-61. PubMed Abstract | Publisher Full Text | Free Full Text

93. Babcock MS, Foster L, Pasquina $P$, et al:: Treatment of pain attributed to plantar fasciitis with botulinum toxin a: a short-term, randomized, placebo-controlled, double-blind study. Am J Phys Med Rehabil. 2005; 84(9): 649-54. PubMed Abstract | Publisher Full Text

94. Breuer B, Sperber K, Wallenstein S, et al.: Clinically significant placebo analgesic response in a pilot trial of botulinum $B$ in patients with hand pain and carpal tunnel syndrome. Pain Med. 2006; 7(1): 16-24. PubMed Abstract | Publisher Full Text

95. Singer BJ, Silbert PL, Dunne JW, et al:: An open label pilot investigation of the efficacy of Botulinum toxin type A [Dysport] injection in the rehabilitation of chronic anterior knee pain. Disabil Rehabil. 2006; 28(11): 707-13. PubMed Abstract | Publisher Full Text

96. Marchini C, Acler M, Bolognari MA, et al.: Efficacy of botulinum toxin type A treatment of functional impairment of degenerative hip joint: Preliminary results. J Rehabil Med. 2010; 42(7): 691-3.

PubMed Abstract | Publisher Full Text

97. Lim JY, Koh JH, Paik NJ: Intramuscular botulinum toxin-A reduces hemiplegic shoulder pain: a randomized, double-blind, comparative study versus intraarticular triamcinolone acetonide. Stroke. 2008; 39(1): 126-31. PubMed Abstract | Publisher Full Text

98. Anderson S, Krug H, Dorman C, et al:: Analgesic effects of intra-articular botulinum toxin Type $B$ in a murine model of chronic degenerative knee arthritis pain. J Pain Res. 2010; 3: 161-8. PubMed Abstract | Publisher Full Text | Free Full Text 


\section{Open Peer Review}

\section{Current Peer Review Status:}

\section{Version 2}

Reviewer Report 27 January 2014

https://doi.org/10.5256/f1000research.1531.r3070

(C) 2014 Brittberg M. This is an open access peer review report distributed under the terms of the Creative Commons Attribution License, which permits unrestricted use, distribution, and reproduction in any medium, provided the original work is properly cited.

\section{Mats Brittberg}

Cartilage Research Unit, University of Gothenburg, Kungsbacka, Sweden

Musculoskeletal pain is a big problem for society. There is need of new and easy performed treatment alternatives. This very comprehensive review on the treatment with botulinum toxins for different musculoskeletal pain disorders is subsequently very welcome for all that treat patients with retractable pain in bone, muscles, and joints. I am happy to recommend a further study of this well written review.

Competing Interests: No competing interests were disclosed.

I confirm that I have read this submission and believe that I have an appropriate level of expertise to confirm that it is of an acceptable scientific standard.

Reviewer Report 21 August 2013

https://doi.org/10.5256/f1000research.1531.r1565

(C) $\mathbf{2 0 1 3}$ Gerwin R. This is an open access peer review report distributed under the terms of the Creative Commons Attribution License, which permits unrestricted use, distribution, and reproduction in any medium, provided the original work is properly cited.

\section{Robert Gerwin}

Pain \& Rehabilitation Medicine, Bethesda, MD, USA

I am now satisfied with the revised paper.

Competing Interests: No competing interests were disclosed.

I confirm that I have read this submission and believe that I have an appropriate level of 
expertise to confirm that it is of an acceptable scientific standard.

Author Response 06 Oct 2013

Jasvinder Singh, Birmingham Veterans Affairs Medical Center, Birmingham AL, USA

We thank Dr. Gerwin for his critique and recommendations.

Competing Interests: same as previously

\section{Version 1}

Reviewer Report 12 March 2013

https://doi.org/10.5256/f1000research.1222.r824

(c) 2013 Funk J. This is an open access peer review report distributed under the terms of the Creative Commons Attribution License, which permits unrestricted use, distribution, and reproduction in any medium, provided the original work is properly cited.

\section{Julia Funk}

Centrum für Muskuloskeletale Chirurgie, Orthopädische Universitätsklinik der Charité, Berlin, Germany

The manuscript is a decent, very detailed, and almost complete review. The title and abstract are appropriate for the content of the article and the conclusions are sensible and justified.

However, I do have two significant reservations. Unfortunately, for a complete review of the published data concerning the topic 'botulinum toxin and pain' we found two RCTs missing: Lin YC (2010) Am J Phys Med Rehabil, Placzek R (2007) JBJS Am.

Furthermore, there have been at least 3 review articles with the same topic in 2012 (Hameed $\mathrm{F}$ (2012), Cheng OT (2012), Sim WS (2011)), hence by reading this manuscript, little information may be new to the informed reader.

Competing Interests: No competing interests were disclosed.

I confirm that I have read this submission and believe that I have an appropriate level of expertise to confirm that it is of an acceptable scientific standard, however I have significant reservations, as outlined above.

Author Response ( ) 21 May 2013

Jasvinder Singh, Birmingham VA Medical Center and Department of Medicine, University of 
Alabama, USA

We thank the reviewers, who provided great insights. The revisions made in response to their comments have improved the quality and clarity of this paper. Here are our responses to the comments from reviewer \#1.

\section{Reviewer comments}

Response to reviewers

Reviewer\#1: Julia Funk, Centrum für Muskuloskeletale Chirurgie, Orthopädische Universitätsklinik der Charité, Berlin, Germany

Status and Report: 12 Mar 2013

The manuscript is a decent, very detailed, and almost complete review. The title and abstract are appropriate for the content of the article and the conclusions are sensible and justified.

Thank you.

However, I do have two significant reservations. Unfortunately, for a complete review of the published data concerning the topic 'botulinum toxin and pain' we found two RCTs missing: Lin YC (2010) Am J Phys Med Rehabil, Placzek R (2007) JBJS Am.

We thank the reviewer for pointing us to the two missing studies, which have now been included in the review.

Furthermore, there have been at least 3 review articles with the same topic in 2012 (Hameed $F$ (2012), Cheng OT (2012), Sim WS (2011)), hence by reading this manuscript, little information may be new to the informed reader.

We thank the reviewer for pointing out these pertinent reviews. We refer to them in our paper and discuss how our review adds to what's already been published. Both Hameed and Cheng et al. were focused on osteoarthritis (OA) treatments only. Our review is more comprehensive in that it includes muscucloskeletal (MSK) pain, not just knee OA or OA.

Sim et al. provides a very brief overview of a few studies of botulinum toxin for any indication, without providing much detail about key studies. Thus, we believe our review adds to the already published reviews, and provides a complete perspective on the potential role of botulinum toxin in the treatment of MSK pain.

"Recent reviews have summarized the injectable treatments for osteoarthritis (64), injectable treatments for knee osteoarthritis (65) or use of neurotoxin for the treatment of painful disorders (66), In this review, we provide a review of evidence regarding Botulinum toxin for the treatment of musculoskeletal pain conditions."

Competing Interests: There are no financial competing interests related directly to this study. JAS has received research and travel grants from Takeda, Savient, and Allergan; and consultant fees from URL pharmaceuticals, Savient, Takeda, Regeneron, Ardea, Allergan and 
Novartis. The views expressed in this article are those of the author and do not necessarily reflect the position or policy of the Department of Veterans Affairs or the United States government.

Reviewer Report 11 March 2013

https://doi.org/10.5256/f1000research.1222.r826

(C) 2013 Gerwin R. This is an open access peer review report distributed under the terms of the Creative Commons Attribution License, which permits unrestricted use, distribution, and reproduction in any medium, provided the original work is properly cited.

\section{Robert Gerwin}

Pain \& Rehabilitation Medicine, Bethesda, MD, USA

This article reviews the use of botulimum toxin in the treatment of pain, rather than in the treatment of muscle contraction. This is a new area of potentially great interest and therefore the review is both timely and presents a new use of botulinum toxin to be considered.

The drawback in the article is that it is a systematic review, not a metaanalysis and not a critical review. As such, it could be shortened by summarizing the studies with less detail. The greater detail in which the cases are described does not add a great detail, since they are simply recapitulations of the study, and do not tell tell us if the study is credible or not. I suggest that the author either be more concise in the summaries, or be more critical in assessing the studies.

Moreover, the author includes both intra-articular injections and intramuscular injections. The intramuscular injections may have complex effects, including; analgesic effects, effects from blocking acetylcholine release from motor nerve endings, and the elimination of muscle myofascial trigger points.

However, the review is incomplete. For example, he discusses low back pain with injections into the lumbar paraspinal musculature, but only gives Ney and Forster as two references. He could have included the work of Gul et al and of DeAndres et al.

The title and abstract are appropriate.

My comments regarding the nature of his review are given above. The conclusion is accurate and justified. There are no experimental data to discuss, since this is a review article.

In summary, the topic is timely, the review summarizes the data from some but not all relevant studies and in that sense is not complete, and the summary does not address the credibility of the articles cited, and that is a weakness. 
Competing Interests: No competing interests were disclosed.

I confirm that I have read this submission and believe that I have an appropriate level of expertise to confirm that it is of an acceptable scientific standard, however I have significant reservations, as outlined above.

Author Response ( ) 21 May 2013

Jasvinder Singh, Birmingham VA Medical Center and Department of Medicine, University of Alabama, USA

We thank the reviewers, who provided great insights. The revisions made in response to their comments have improved the quality and clarity of this paper. Here are our responses to the comments from reviewer \#2.

\section{Reviewer comments}

Response to reviewers

Robert Gerwin, Pain \& Rehabilitation Medicine, Bethesda, MD, USA

Status and Report: 11 Mar 2013

This article reviews the use of botulimum toxin in the treatment of pain, rather than in the treatment of muscle contraction. This is a new area of potentially great interest and therefore the review is both timely and presents a new use of botulinum toxin to be considered.

Thank you.

The drawback in the article is that it is a systematic review, not a metaanalysis and not a critical review. As such, it could be shortened by summarizing the studies with less detail. The greater detail in which the cases are described does not add a great detail, since they are simply recapitulations of the study, and do not tell tell us if the study is credible or not. I suggest that the author either be more concise in the summaries, or be more critical in assessing the studies.

We agree and have listed this as a limitation of our review. We have added an overall limitation section for our review. We have also added a section of comments related to study strengths and weaknesses of each indication to provide a more critical assessment of each study.

"Summary and Study limitations: plantar fasciitis In summary, the evidence is based on one non-randomized study and one RCT. Pain and function both improved short-term in botulinum toxin compared to placebo at 3- and 8-week follow-up in RCT and pain improved up to 1-year follow-up in non-randomized study. While the data seems promising, more RCTs are needed and evidence of efficacy at longer-term is needed to assess whether botulinum toxin can provide a longer-term relief in patients with plantar fasciitis."

"Limitations of this review This was a focused review of randomized and non-randomized studies, not a systematic review or a meta-analysis. Therefore findings must be interpreted 
with caution. In particular, the summary section for various musculoskeletal pain disorders highlights the limitation of studies included. In particular, evidence for the efficacy of botulinum toxin in anterior knee pain and hip pain was based on non-randomized study data only (one study for each), and is subject to bias. The intramuscular injections may have complex effects, including the analgesic effects, effects from blocking acetylcholine release from motor nerve endings, and the elimination of muscle myofascial trigger points. On the other hand, intraarticular injections may work primarily by their effect on the analgesic pathways."

Moreover, the author includes both intra-articular injections and intramuscular injections. The intramuscular injections may have complex effects, including; analgesic effects, effects from blocking acetylcholine release from motor nerve endings, and the elimination of muscle myofascial trigger points.

We agree that intramuscular and intra-articular injections likely have different mechanisms of action. Both types of injections are commonly used in the treatment of MSK pain, the focus of our paper. We mention the important point brought up by the reviewer in the discussion of results.

However, the review is incomplete. For example, he discusses low back pain with injections into the lumbar paraspinal musculature, but only gives Ney and Forster as two references. He could have included the work of Gul et al and of DeAndres et al.

We have now added DeAndres et al. and Lew et al. to our review. We are sorry but could not find Gul et al.

The title and abstract are appropriate.

Thank you.

My comments regarding the nature of his review are given above. The conclusion is accurate and justified. There are no experimental data to discuss, since this is a review article.

Thank you.

In summary, the topic is timely, the review summarizes the data from some but not all relevant studies and in that sense is not complete, and the summary does not address the credibility of the articles cited, and that is a weakness.

We have now included the additional studies pointed out by the reviewer. We have also added statements related to the credibility of each studies for each condition (please see responses to reviewer comments in the sections above and the changes in the revised article).

Competing Interests: There are no financial competing interests related directly to this study. JAS has received research and travel grants from Takeda, Savient, and Allergan; and 
consultant fees from URL pharmaceuticals, Savient, Takeda, Regeneron, Ardea, Allergan and Novartis. The views expressed in this article are those of the author and do not necessarily reflect the position or policy of the Department of Veterans Affairs or the United States government.

The benefits of publishing with F1000Research:

- Your article is published within days, with no editorial bias

- You can publish traditional articles, null/negative results, case reports, data notes and more

- The peer review process is transparent and collaborative

- Your article is indexed in PubMed after passing peer review

- Dedicated customer support at every stage

For pre-submission enquiries, contact research@f1000.com 